\title{
Power and Energy Analysis for a Commercial Retail Refrigeration System Responding to a Static Demand Side Response
}

\author{
Ibrahim M. Albayati a, *, Andrey Postnikov a, ${ }^{\text {, }}$, Simon Pearson ${ }^{\text {b }}$, Ronald Bickerton a ${ }^{\text {a }}$ Argyrios Zolotas a, 2 , and Chris Bingham ${ }^{\text {a }}$ \\ ${ }^{a}$ School of Engineering, University of Lincoln, Brayford Pool, Lincoln, LN6 7TS, UK. \\ ${ }^{\mathrm{b}}$ Lincoln Institute of Agri-Food Technology, University of Lincoln, Riseholme Park, Lincoln, LN2 2LG, UK. \\ Email address: ialbayati@lincoln.ac.uk (I.M.A.); apostnikov@lincoln.ac.uk (A.P.); spearson@lincoln.ac.uk (S.P.); \\ rbickerton@lincoln.ac.uk (R.B.); azolotas@lincoln.ac.uk (A.Z.); cbingham@lincoln.ac.uk (C.B.). \\ ${ }^{*}$ Corresponding author: ialbayati@lincoln.ac.uk (I.M.A.).
}

\begin{abstract}
The paper considers the impact of Demand Side Response events on supply power profile and energy efficiency of widely distributed aggregated loads applied across commercial refrigeration systems. Responses to secondary grid frequency static DSR events are investigated. Experimental trials are conducted on a system of refrigerators representing a small retail store, and subsequently on the refrigerators of an operational superstore in the UK. Energy consumption and energy savings during 3 hours of operation, pre and post-secondary DSR, are discussed. In addition, a simultaneous secondary DSR event is realised across three operational retail stores located in different geographical regions of the UK. A Simulink model for a $3 \Phi$ power network is used to investigate the impact of a synchronised return to normal operation of the aggregated refrigeration systems post DSR on the local power network. Results show $\sim 1 \%$ drop in line voltage due to the synchronised return to operation. An analysis of energy consumption shows that DSR events can facilitate energy savings of between $3.8 \%$ and $9.3 \%$ compared to normal operation. This is a result of the refrigerators operating more efficiently during and shortly after the DSR. The use of aggregated refrigeration loads can contribute to the necessary load-shed by $97.3 \%$ at the beginning of DSR and $27 \%$ during 30 minutes DSR, based on a simultaneous DSR event carried out on three retail stores.
\end{abstract}

Keywords: Demand Side Response, Firm Frequency Response, National Grid, Retail Refrigeration System, Candidacy Algorithm, Power Profile.

\begin{tabular}{|llll|}
\hline Abbreviations and Nomenclature & & \\
CPT & calculated product temperature in ${ }^{\circ} \mathrm{C}$ & $P_{o}$ & power, in $\mathrm{kW}$ \\
DSR & demand side response & $T$ & temperature, in ${ }^{\circ} \mathrm{C}$ \\
$E$ & energy, in $\mathrm{kWh}$ & $T_{\text {air-off }}$ & temperature of the cold air, in ${ }^{\circ} \mathrm{C}$ \\
$F$ & frequency, in $\mathrm{Hz}$ & $T_{\text {air-off }}$ & temperature of the inlet air, in ${ }^{\circ} \mathrm{C}$ \\
FFR & firm frequency response & $T_{\text {shelf }}$ & shelf temperature, in ${ }^{\circ} \mathrm{C}$ \\
HT & high temperature cases, in ${ }^{\circ} \mathrm{C}$ & $T_{\text {shelf }}^{k}$ & shelf temperature at $k$ th minute, in ${ }^{\circ} \mathrm{C}$ \\
LT & low temperature cases, in ${ }^{\circ} \mathrm{C}$ & $t$ & time in (second, minute, hour) \\
$P$ & suction pressure in bar & $V$ & line voltage in volt \\
\hline
\end{tabular}

\section{Introduction}

The power system infrastructure of many countries is experiencing escalating supply pressures due to significant increases in electrical demand and the increased penetration of renewable power sources on the grid. It is known that non-stiff renewable sources can induce imbalance and peak capacity problems over the entire network [1]. In view of these pressures, the UK National Grid has introduced a scheme of Firm Frequency Response (FFR) to balance power supply and demand, where Demand Side Response (DSR) is considered a vital stability mechanism and triggered when the grid frequency drops below a predefined level $[1,2]$. Frequency stabilization within a narrow band of $50 \mathrm{~Hz}$ is traditionally accomplished through frequency response services either by regulating the load or increasing the available supply. This also prevents the sudden failure of power plant and blackouts [3]. With regard to Demand Side Response (DSR) the firm frequency response (FFR) can be delivered in either dynamic or non-dynamic (static) modes. Dynamic frequency response is a service that continuously manages the normal secondby-second changes of the grid frequency by exciting loads that track set changes of frequency, whilst a non-dynamic frequency response is a discrete service triggered when a predefined frequency deviation occurs [3, 4]. For the static mechanism, two phases of FFR (primary and secondary) are considered, see Figure 1. During the primary FFR period, the load contributing to the

\footnotetext{
${ }^{1}$ Andrey Postnikov, was a Research Fellow in Control Systems at the University of Lincoln-School of Engineering, where the work presented in this paper was achieved. He is now a Research Associate in the Department of Civil, Environmental and Geomatic Engineering, UCL, University College London, Gower Street, London, WC1E 6BT, UK. E-mail: a.postnikov@ucl.ac.uk.

${ }^{2}$ Argyrios Zolotas, was a Reader at the University of Lincoln-School of Engineering, where the work presented in this paper was achieved. He is now Reader with SATM, University of Cranfield. Cranfield, Bedfordshire, MK43 0AL, UK. E-mail: argyrios.zolotas@cranfield.ac.uk.
} 
DSR must respond within 10 seconds and the load that is shed must be held off for a further 20 seconds. During the secondary FFR phase, the load shed must respond within 30 seconds of an event and be sustained for a further 30 minutes. The response depicted in Figure 1, which includes both primary and secondary FFR, must arrest the frequency drop and contribute to its recovery once the nadir (i.e. the lowest point) is reached. The start of a non-dynamic (FFR-DSR) is triggered when the frequency of the electrical grid falls to a predefined level (e.g. $49.7 \mathrm{~Hz}$ for the UK), when the entire load contributing to the DSR must respond and shed rapidly [4].

Financial benefits for delivering primary and secondary FFR reflects the magnitude of contracted load shed. According to UK's National Grid, the minimum load tender is $10 \mathrm{MW}$, which can be deployed through shedding power of a single large load or via aggregating large numbers of smaller disturbed loads [5-9]. The food industry in the UK could play a significant role in supporting DSR mechanisms. It represents the largest manufacturing sector with retail food alone accounting of around $12 \mathrm{TWh}$ of energy consumption per annum, equating to approximately $3.4 \%$ of the UK total [10]. Retail refrigeration systems, along with HVAC are estimated to consume around $14 \%$ of the UK's electricity, thereby offering significant potential for the application of DSR. Additionally, the thermal inertia of food creates a significant opportunity to shift electrical, and the cold energy stored in the relatively large product mass (in cold stores, freezers, refrigerators, etc) will be the UK's largest source of energy store [11, 12].

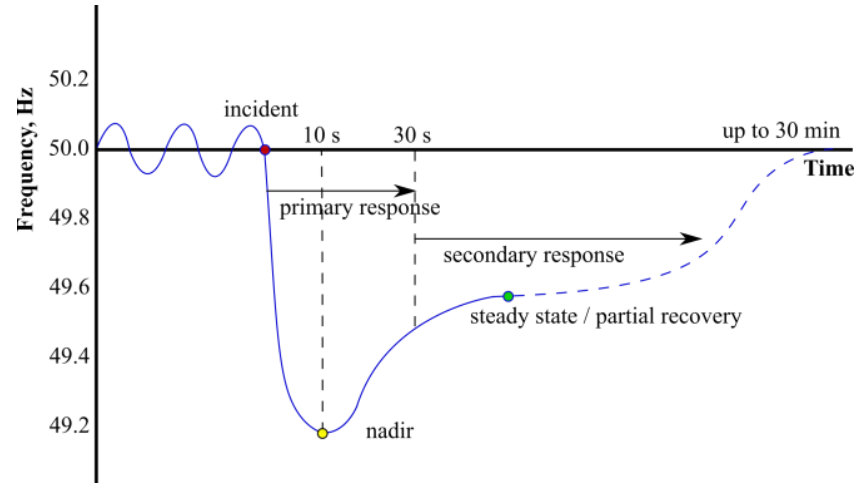

Figure 1: Overview of Firm Frequency Response of National Grid (cited from [13]).

For the food sector, demand side management for end-users has been previously investigated in detail in [14, 15] with the latter reporting that retail stores comprised of diverse load types such as lights, freezers and fridges, ventilation and ovens, can be considered rich assets rich for providing DSR services. The investigation reported in [16] proposed a dynamic frequency control technique to determine the available capacity of aggregated loads for domestic heat pumps and fridges to facilitate firm frequency response. However, the profile of retail stores are characterized with large numbers of assets each requiring relatively low individual electrical loads [16]. For example, one of the leading food retailers in the UK has $>100,000$ refrigeration cases distributed over more than 3500 stores. However, the application of FFR DSR in the food refrigeration sector is complex and poses significant technical challenges. The rapid control of refrigerators, commensurate with the requirements for primary and secondary DSR events across an entire estate whilst ensuring the availability of sufficient thermal inertia to keep food within safety boundaries, is extremely challenging, and requires timely measurements or predictions of changes of thermal inertia of individual refrigeration systems [17, 18]. Essential requirements are for fast and reliable IT infrastructures that can handle large amounts of high bandwidth data streams $[19,20]$, and supervisory controllers to monitor and control distributed sub-controllers [1]. To date, most existing DSR business models for food focus on improving operation or emergency response for domestic refrigerators, or for a simple system where a single case is cooled by a single compressor, with comparatively few studies examining the impact of DSR during and after the load recovery interval for large networks of retail refrigeration systems [21]. The impact of responding to a DSR event on voltage stability of the power network, and hence on the overall stability of the entire power system, is investigated in [2,21], which shows that both the type and size of the load shed and the stiffness characteristics of the power network affect the electrical characteristics. Moreover, previously reported studies have also considered problems of power synchronization during post-DSR periods, and the subsequent impact of generating significant transient demands from refrigeration systems [22, 23]. Whilst control and protection devices can act to lower power fluctuations on the system, the overall stability of the power grid and the risk of network failure remains an active problem [24, 25]. Other studies have also reported that a large network of refrigerators can initiate a sequential under-frequency event particularly after switching systems from off-to-on and returning to normal operation [26]. A stochastic decentralized control is reported to be beneficial in alleviating the impact of power oscillations when using small groups of domestic refrigerators, but incurs a high computational demand $[3,27,28]$. The proposal by a research group at the University of Lincoln (UK) in [11, 13, 29] addressed the risks and challenges associated with the DSR event viz. how the temperature-pressure profile of the system and how the active power and the current of the compressors are affected following a primary FFR DSR. The studies also showed the impact 
of the significant inrush currents after a primary FFR DSR event which can produce voltage fluctuations of the supply, and the risks to the local power supply system.

Here, this paper investigates how the power profile of the refrigeration system is affected following a secondary FFR DSR and subsequent return to normal operation. Active power profiles for refrigeration systems responding DSR events are experimentally investigated and then used to analyse the impact of the subsequent re-synchronization of many thousands of refrigeration loads at turn-ON, post DSR, and the implications for local power supply networks. Measurements from various DSR scenarios are considered for different operational and cooling capacity of single and multi-pack refrigeration systems corresponding to small and large retail stores, located in five different geographical regions in the UK (Lincoln, Buckingham, Holbeach, Chesterfield, and Grover Green)—see Figure 2. Moreover, a simultaneous secondary FFR DSR event is subsequently implemented on three of the retail stores. Further, a simulation model of a $3 \Phi$ power network is then used to show the impact of the synchronised switching of packs of compressors and the resulting transient power consumption, post-DSR, on the local power network line voltage.

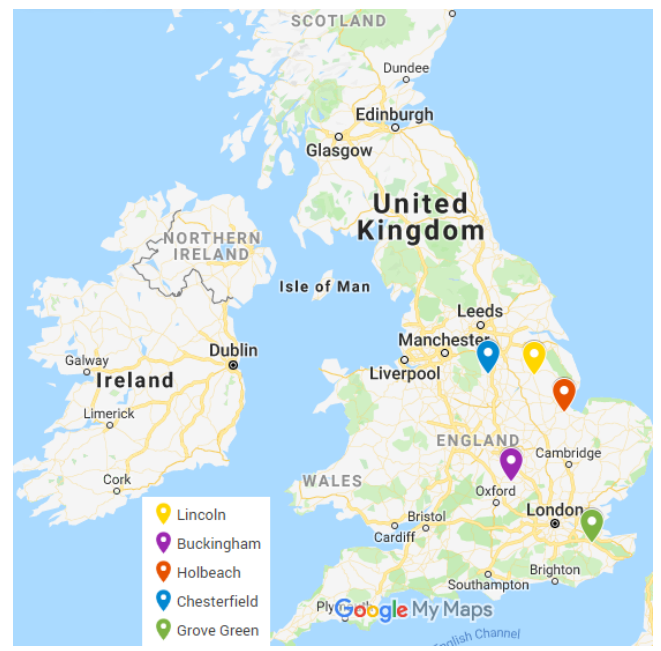

Figure 2: Site locations for five retail commercial stores in the UK.

\section{Demand Side Response for a Single Small Refrigeration System}

An instrumented refrigeration system representing a small retail store is available at the Refrigeration Research Centre at the University of Lincoln, UK. Figure 3 shows, respectively, the pack of compressors and high temperature cases installed at the site. The complete facility comprises of 13 high temperature HT cases and 2 low temperature LT cases, 2 fan condenser units and a pack of Copeland Scroll compressors: 4 identical HT compressors and 2 LT compressors of various sizes. All compressors operate as fixed volume displacement machines. The compressors receive refrigerant through separate HT and LT suction lines that feed a common discharge pipeline, thereby providing one-stage compression for refrigerant from both HT and LT cases. Case control set-points vary from -2 to $1{ }^{\circ} \mathrm{C}$ for HT cases and $-23{ }^{\circ} \mathrm{C}$ for LT cases with a nominal acceptable temperature differential set to $2{ }^{\circ} \mathrm{C}$ for all cases. Expansion valves are used in 'modulate mode'. The compressors are controlled by Danfoss 531B to maintain suction pressure in both the HT and LT lines within the operational recommended level. A multifunction meter (DIRIS A40/A41) is installed to measure power consumption with a $1 \mathrm{~Hz}$ sampling frequency.

The suction pressure of the system and the temperature measurements for 24 hours of normal operation for the HT and LT case, is shown in Figure 4. For HT cases, the defrost schedule consists of 4 defrost cycles per day Figure 4(a), and 2 defrost cycles for LT cases Figure 4(b). Defrost is terminated either by reaching a predetermined time schedule (typically $30-40 \mathrm{~min}$ ), or by reaching a pre-defined case temperature $\left(8^{\circ} \mathrm{C}\right.$ for HT cases) according to manufacturer design specifications. Suction pressure set-points are 3.4 bar for HT compressors, Figure 4(c), and 0.7 bar for LT compressors, Figure 4(d). The estimated shelf temperature $T_{\text {shelf }}$ is a linear combination of air-off and air-on temperatures as in Eq. (1), where $T_{\text {air-off }}$ represents the temperature of the cold air carried away from the evaporator, and $T_{\text {air-on }}$ represents the temperature of the inlet air to the system. The calculated product temperature (CPT) represents a 30 min moving average filtered measurement from air-on and air-off probes, as given by (2) [30], where $T_{\text {shelf }}^{k}$ is the shelf temperature at the kth minute:

$T_{\text {shelf }}=0.6 T_{\text {air-off }}+0.4 T_{\text {air-on }}$

$C P T_{k}=\frac{1}{30}\left(\sum_{i=1}^{29} C P T_{k-i}+T_{\text {shelf }}^{k}\right)$ 


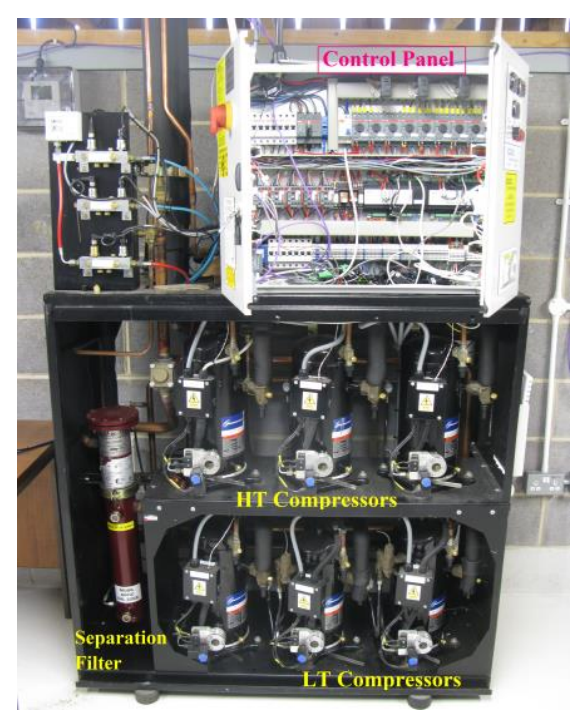

(a) Pack of Compressors

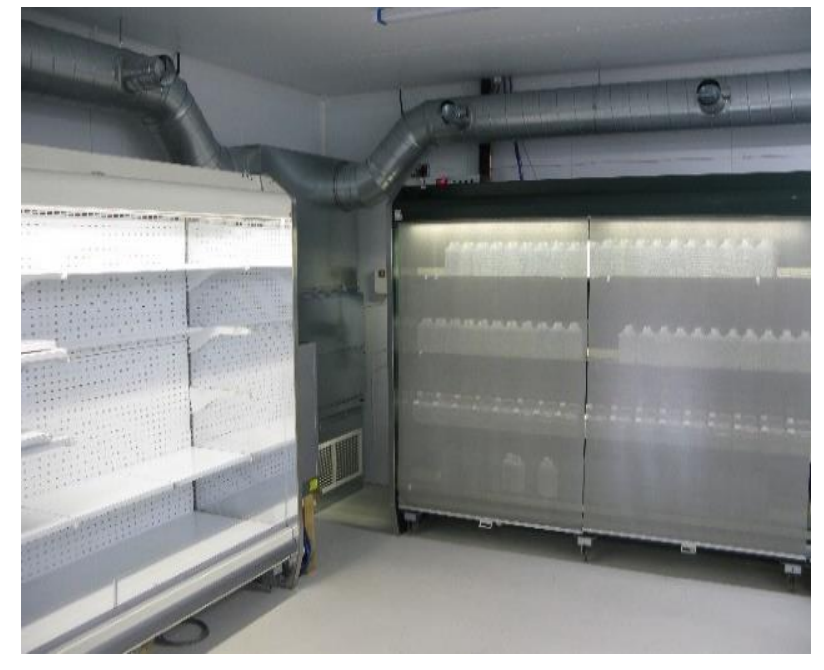

(b) Refrigeration cases

Figure 3: Refrigeration Research Centre at University of Lincoln; (a) Pack of compressors, (b) Refrigeration cases.

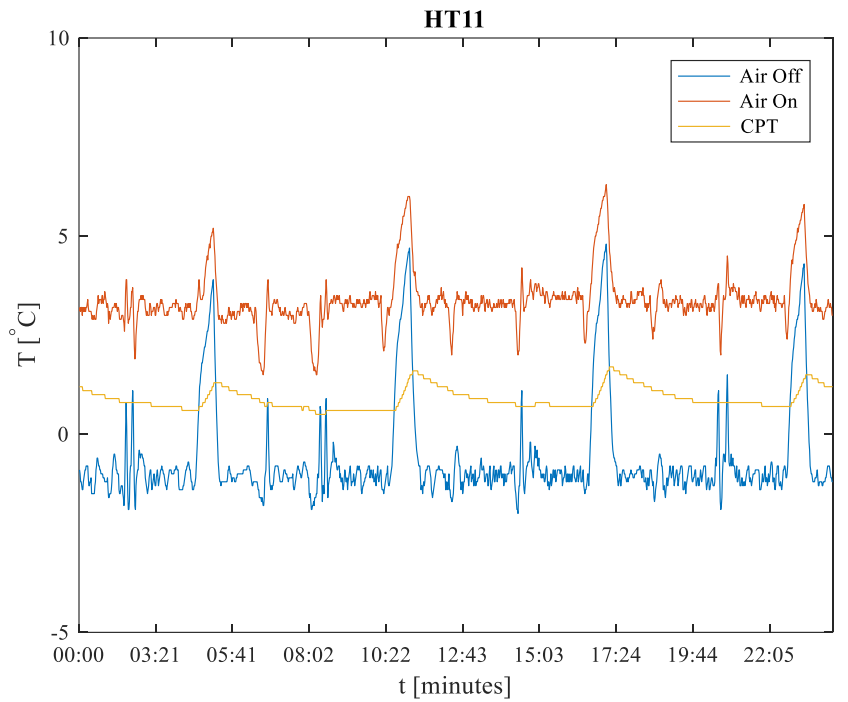

(a) HT case temperature

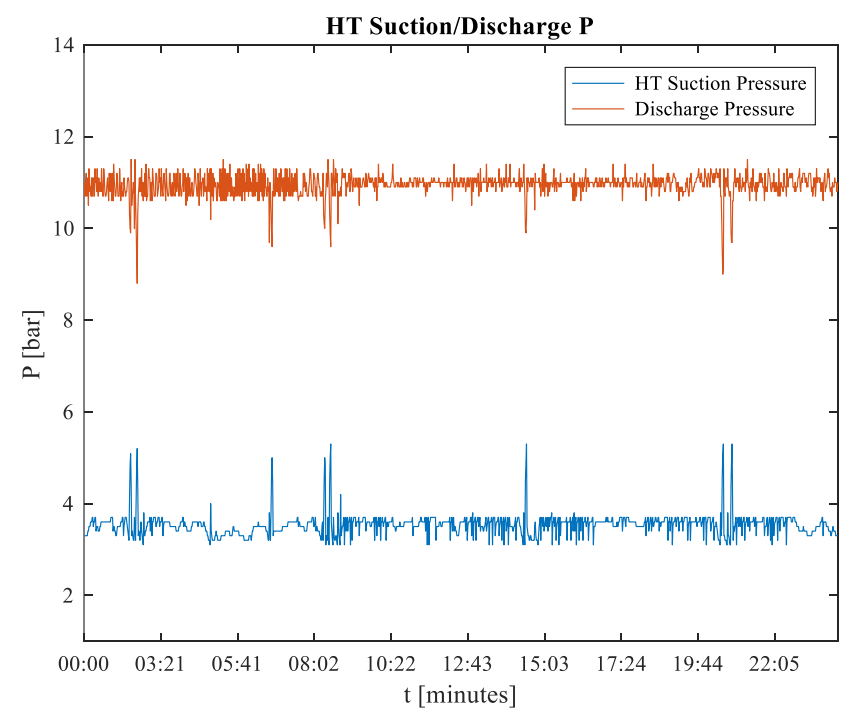

(c) HT suction and discharge pressure

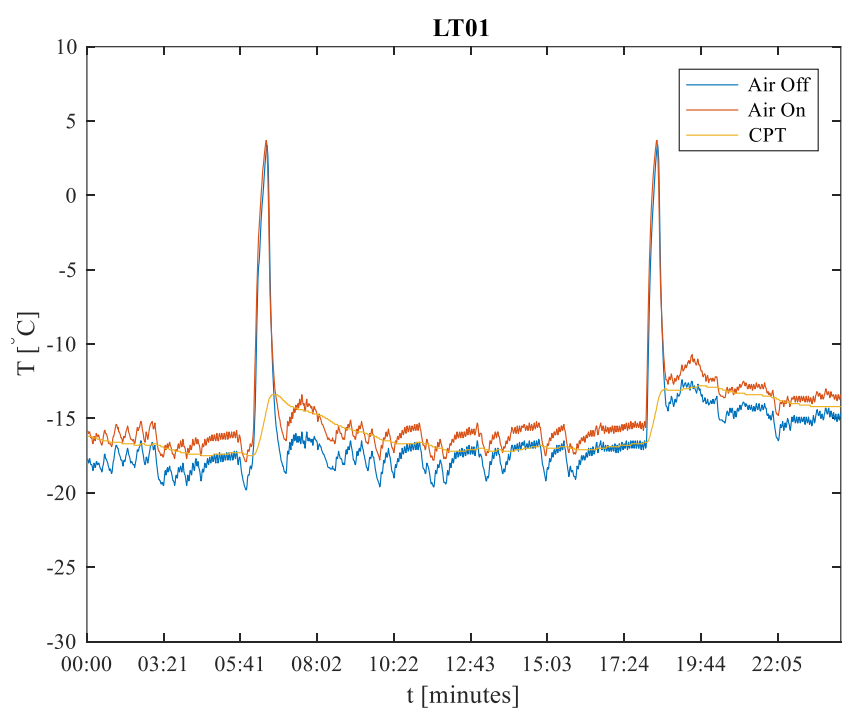

(b) LT case temperature

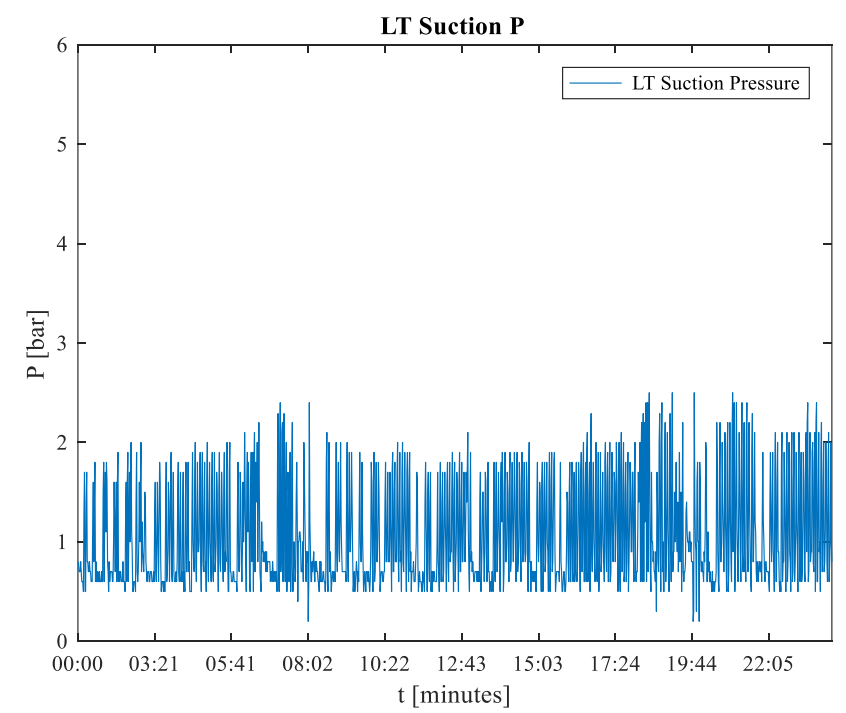

(d) LT suction pressure

Figure 4: Temperature and suction pressure data recorded for 24 hours of normal operation of the refrigeration system. 
The average power consumed during the $30 \mathrm{~min}$ DSR event is monitored, as is the average power consumption over 90 minutes of normal operation prior to triggering a DSR event which is used to provide reference baseline of normal operating conditions. The measurements allow the calculation of the energy requirements necessary to return to nominal operation post-DSR. To investigate the consequences of a DSR on overall refrigeration performance, the energy consumption during 3 hours of system operation is determined from (3), where $E_{1}$ represents the energy consumption for 90 minutes before DSR, $E_{2}$ is the consumption for 30 minutes during DSR, and $\left(E_{3}+E_{4}\right)$ is the consumption for 60 minutes after exiting a DSR event. The energy consumption over 60 minutes after exiting DSR event is divided into $2 \times 30$ min intervals $\left(E_{3}+E_{4}\right)$ in order to identify whether the energy consumed during the first interval is higher or lower than that during the second interval. This assists in determining when the maximum operational stress on the power system occurs.

Energy Saving $=E_{1}-\left(E_{2}+E_{3}+E_{4}\right)$

Defrost cycles are scheduled to be at the beginning of the hour, and executed by shutting down the LT system valves for 30 minutes and putting HT systems on defrost for 40 minutes (or until the HT system leaves defrost by reaching the $8{ }^{\circ} \mathrm{C}$ temperature limit), which is then followed by a re-cooling period (i.e. reducing the temperature of the cases to the nominal set point). The expansion valves are operated in a 'modulated mode'. The secondary FFR DSR event is triggered by putting cases and cold rooms in a defrost mode, then after 25 seconds the pack of 6 compressors is turned OFF (pulsing OFF-ON), allowing the remaining refrigerant in the system to flow back to the suction line of the pack, which provides a reduction in power consumption during the DSR event.

Tests carried out on the refrigeration systems in response to the DSR are summarized in Appendix A Table A.1, and Figures 5-8, respectively. It is notable that post DSR there is a steady increase in power consumption for 6-8 minutes after the cases and cold rooms exit their defrost cycle by time termination, as shown in Figures 5 and 6. Figure 5 shows a sudden increase in power when returning to its normal offset after exiting the DSR event; the system returned to normal power consumption 42 min after exiting the DSR. Figure 6 shows an increase in energy consumption by $\sim 0.7 \mathrm{kWh}$ during DSR when compared with that of Figure 5 (associated with applying an offset), which is due to the demand on refrigerant by a re-cooling process which is occurred during the DSR event Figure 6. The system returned to normal operating power consumption 19 min after exiting the DSR.

To reduce the power peak during the re-cooling process (i.e. exiting defrost), the termination time of the defrost cycle for the HT Cases (1-5) is extended from 30 to 90 minutes to force the defrost to (instead) terminate by hitting the set point temp $8{ }^{\circ} \mathrm{C}$ (temperature termination). Figure 7 shows that the peak power due to the re-cooling process (post exiting Defrost) remains relatively steady for around 15 minutes as a result of this, and provides the operational advantage of reducing the stress on the local electrical power network. Moreover, applying a pressure offset aids in moving the re-cooling process out of the DSR period, as also shown in Figures 5-8, respectively. However, further investigation into the effect on food safety (since the actual temperature profile is not known) needs to be undertaken before the 'temperature termination' scenario can be widely adopted.

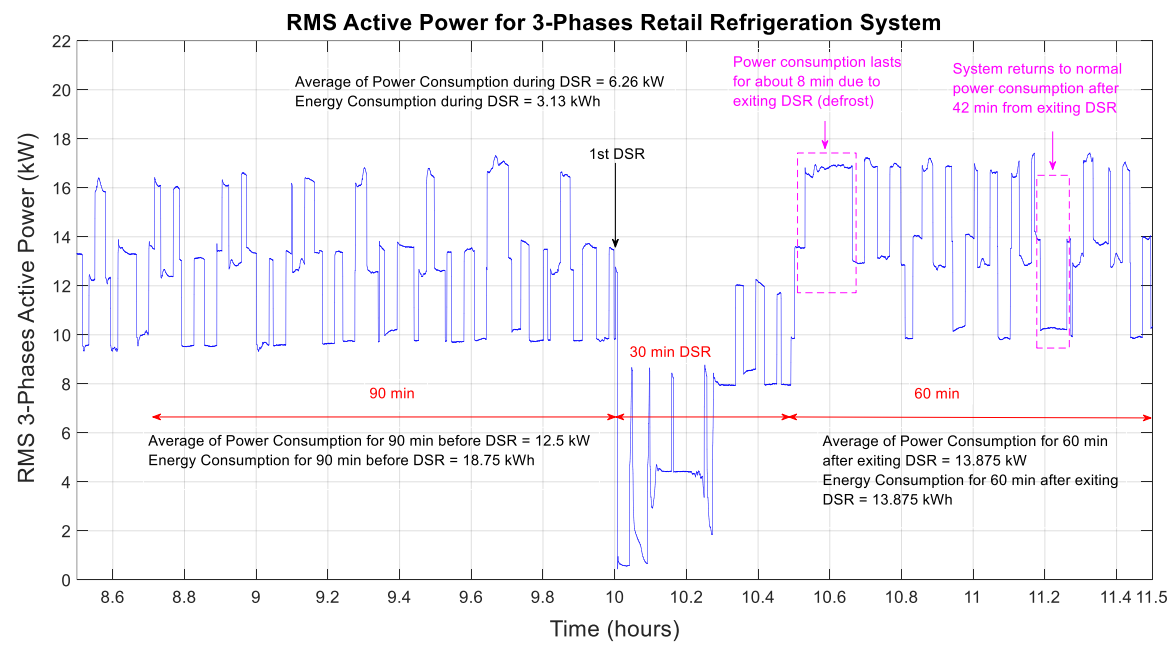

Figure 5: RMS power consumption for a single pack of 6 compressors, when placing all cases \& cold rooms in secondary FFR DSR, associated with applying pressure offset (HT from 3.4 to 4 bar, LT from 0.7 to 1.3 bar), for 30 min, DSR is triggered at 10:00 am (Test no 1, Table A.1). 


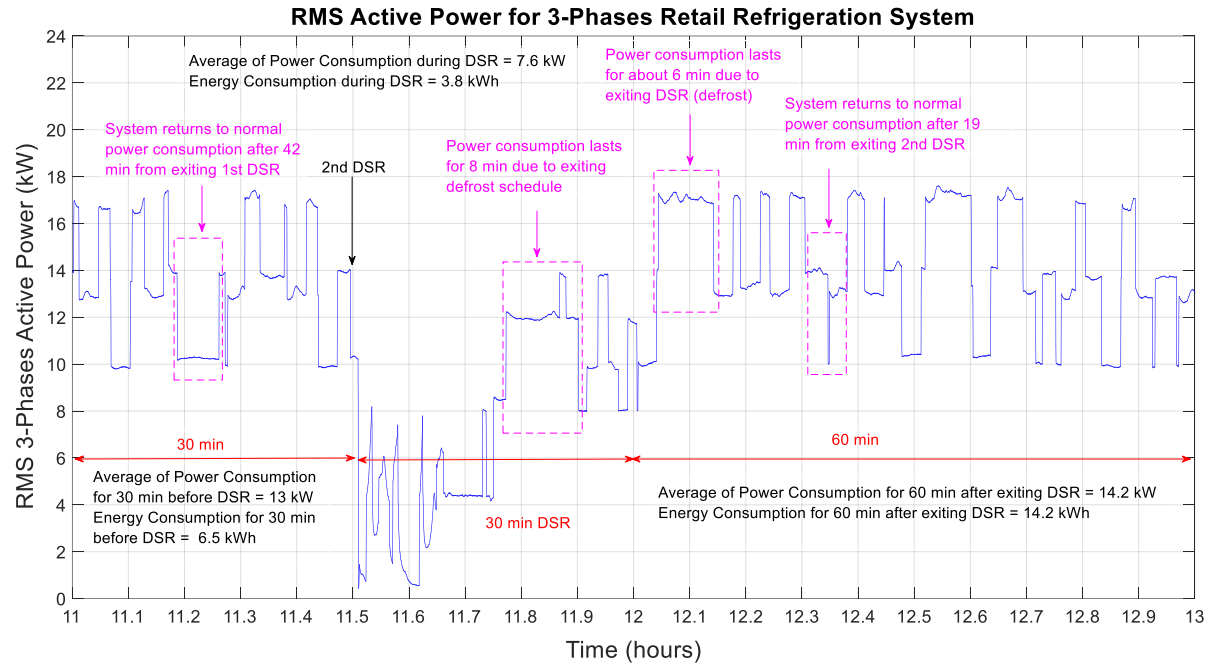

Figure 6: RMS power consumption for a single pack of 6 compressors, when placing all cases \& cold rooms in secondary FFR DSR, without applying pressure offset, DSR is triggered at 11:30 am (Test no 2, Table A.1).

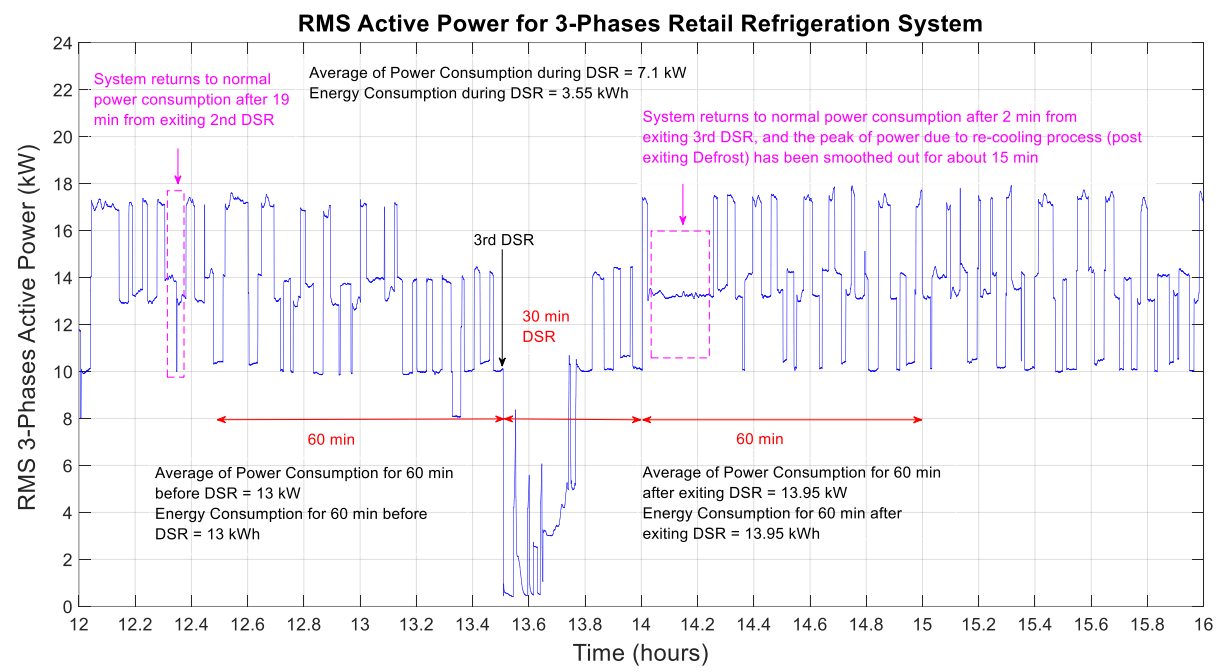

Figure 7: RMS power consumption for a single pack of 6 compressors, when placing all cases \& cold rooms in secondary FFR DSR, associated with applying pressure offset (HT from 3.4 to 4 bar, LT from 0.7 to $1.3 \mathrm{bar}$ ), for $30 \mathrm{~min}$, and the termination time of defrost for the HT Cases (1-5) is extended from 30 to 90 mins, DSR is triggered at 13:30 pm (Test no 3, Table A.1).

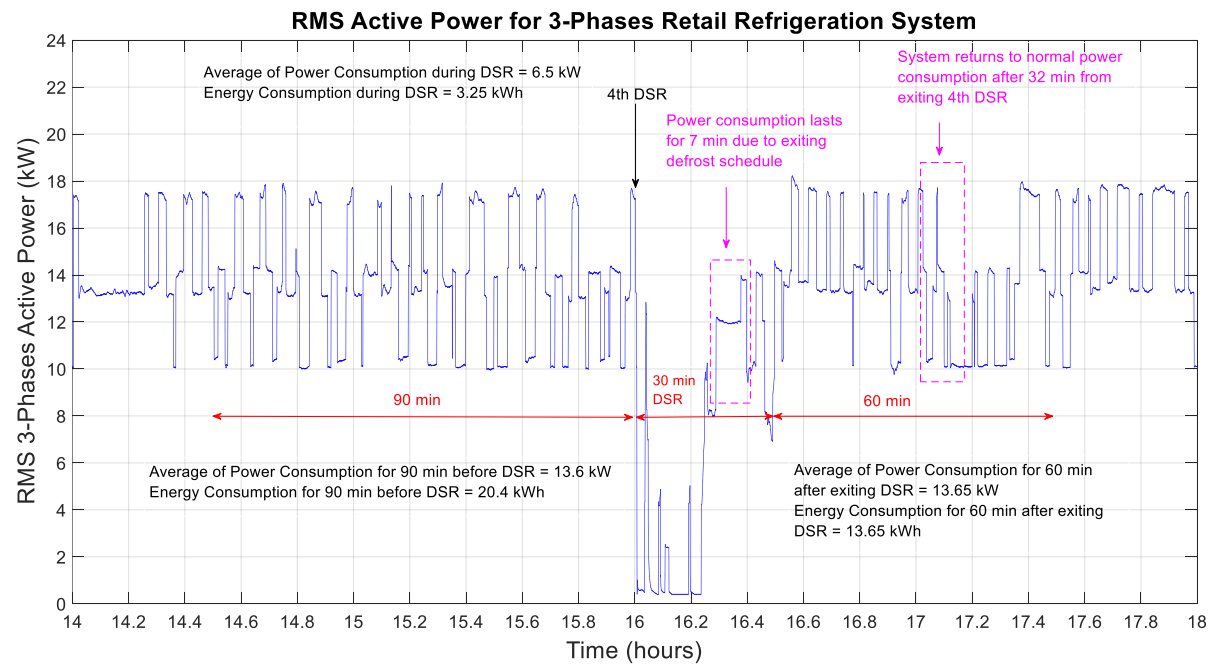

Figure 8: RMS power consumption for a single pack of 6 compressors, with putting all cases \& cold rooms in secondary FFR DSR, without applying pressure offset, and the termination time of defrost for the HT Cases (1-5) is extended from 30 to 90 mins, DSR is triggered at 16:00 pm, (Test no 4, Table A.1). 


\section{Demand Side Response for a Single Large Refrigeration System}

The previous set of tests were carried out on a single pack of compressors with all cases and cold rooms contributing to the DSR regardless the status of their thermal inertia and cooling capacity. In reality, a candidacy algorithm and controlled recovery strategy is vital to determine the rules of selecting stores prior responding to DSR or to discrete pack systems in a single store, in order to provide a reliable and efficient control mechanism to handle DSR events appropriately within the tolerance of the cooling capacity of the refrigeration system. Therefore, to avoid performing DSR when a refrigerator is in defrost or is recovering after a defrost, see Figure 4, such units are now excluded from participating in DSR events (in order to not jeopardise food safety). A developed candidacy algorithm is presented in Figure 9, based on five major criteria: (1) store availability, (2) pack availability, (3) case availability (e.g. fridge, freezer, and cold room), and (4) energy availability (i.e. sufficient product thermal inertia to accommodate the lack of refrigeration over the DSR period) (5) load availability.

A commercial retail superstore facility at Buckingham-UK is initially used to provide a candidate large scale single refrigeration system $(\sim 9 \times$ bigger in terms of the operational capacity than the Refrigeration Research Centre at UoL), comprising of 6 packs of compressors, 4 HT packs operated by 40 compressors, and 2 LT packs operated by 16 compressors, serving 102 HT and LT cases and cold rooms. The packs receive and feed refrigerant through separate HT and LT suction and discharge pipelines.

The presented tests investigate two different scheduling scenarios for system defrost (i) every 60 mins (schedule 1), and (ii) every 40 mins (schedule 2), as shown by example in Figure 10. Defrost (schedule 1) begins at the start of each hour followed by a re-cooling period that always begins at the last $15 \mathrm{~min}$ of the hour and continues for 15 minutes (i.e. reducing the temperature of the cases back to their respective set points); see Figure 10(a). The increase in power consumption during the re-cooling process imparts an additional power requirement of up to $20 \mathrm{~kW}$. The average power consumption before the re-cooling process is $\sim 57.4 \mathrm{~kW}$, and $67.8 \mathrm{~kW}$ during the re-cooling process. Hence, the average power requirement to support the re-cooling process is $\sim 10 \mathrm{~kW}$ above base load (although it could be higher depending on refrigerant demand). Responses to the second defrost schedule scenario are shown in Figure 10(b) - as one batch of systems complete a defrost, the next batch then goes into defrost. The re-cooling processes notably occurs approximately every 40 minutes. The average power consumption due to the re-cooling process is approximately equal to that during the (schedule 1) defrost (i.e. every hour), but the re-cooling time taken by the schedule 2 defrost (i.e. every 40 minutes) is 6-8 minutes shorter.

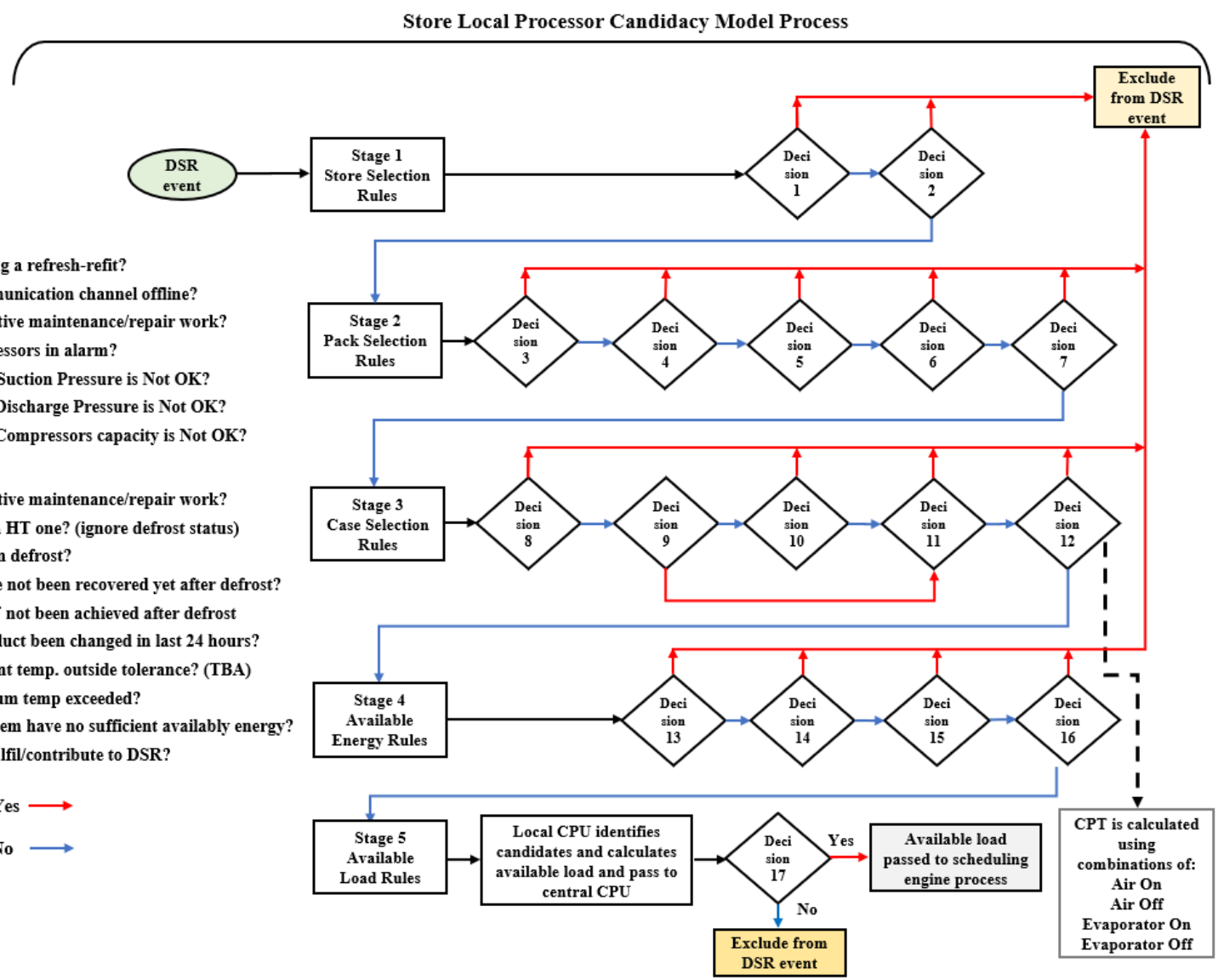

Decision-1: Is Store having a refresh-refit? Decision-2: Is Store communication channel offline? Decision-3: Is there an active maintenance/repair work? Decision-4: Is the Compressors in alarm? Decision-5: Is the Pack's Suction Pressure is Not OK? Decision-6: is the Pack's Discharge Pressure is Not OK? Decision-7: is the Pack's Compressors capacity is Not OK?

Decision-8: Is there an active maintenance/repair work? Decision-9: Is the Case an HT one? (ignore defrost status) Decision-10: Is the Case in defrost? Decision-11: Has the Case not been recovered yet after defrost? Decision-12: Has the CPT not been achieved after defrost Decision-13: Has the product been changed in last 24 hours? Decision-14: Is the ambient temp. outside tolerance? (TBA) Decision-15: FSA maximum temp exceeded? Decision-16: Is entire system have no sufficient availably energy? Decision-17: Can Store fulfil/contribute to DSR?

$$
\begin{aligned}
& \text { Yes } \longrightarrow \\
& \text { No } \longrightarrow
\end{aligned}
$$




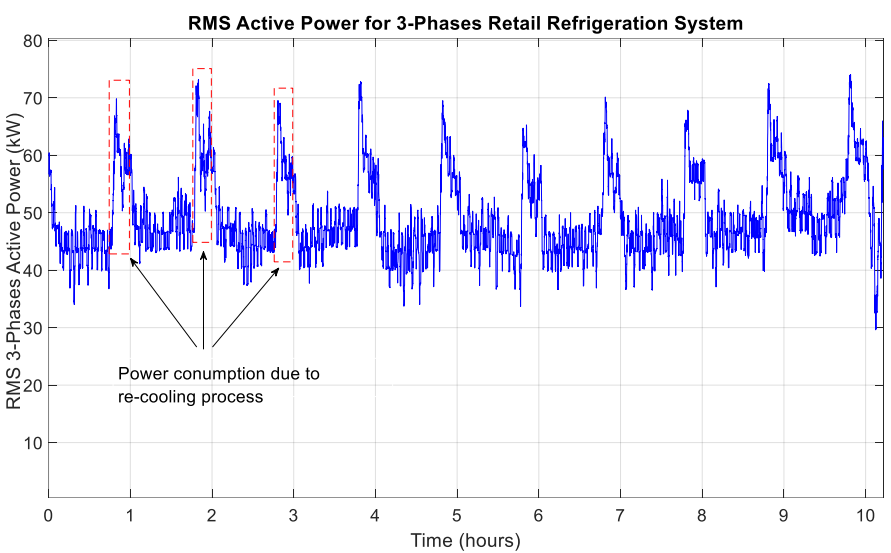

(a) Power consumption due to re-cooling process following a defrost cycle (schedule 1).

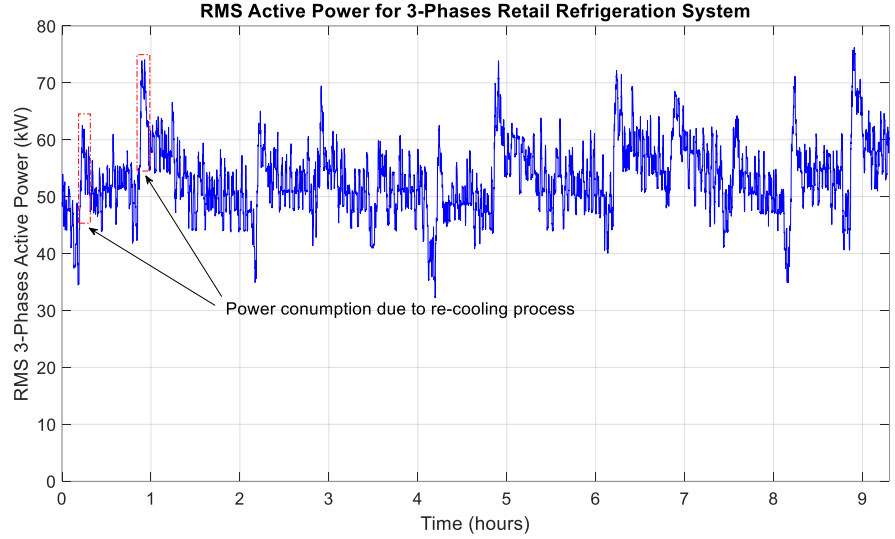

b) Power consumption due to re-cooling process following a defrost cycle (schedule 2).

Figure 10: RMS Power consumption due to re-cooling process following a defrost cycle for 6 packs of compressors at Buckingham Store.

The next, measurements are taken to investigate the impact of various response scenarios to secondary FFR DSR events which are triggered for two different defrost schedules (i.e. schedule 1 for every hour defrost cycle, and schedule 2 for every 40 minutes defrost cycle based on the candidacy algorithm), for two scenarios (i) 'with' a pressure offset and (ii) 'without' applying a pressure offset. The DSR event is triggered by putting the cases and cold rooms into defrost by shutting down the valves of LT cases for 30 minutes and putting HT cases on defrost for 40 minutes (or until the HT system leaves defrost by reaching the $8{ }^{\circ} \mathrm{C}$ temperature limit), then after 25 seconds all the 6 packs are turned OFF (pulsing OFF-ON), thereby allowing the remaining refrigerant in the system to flow back to the suction line of the compressors (again providing a reduction in power consumption during the DSR event). Details of each test are summarized in Appendix A, Table A.2, tests 1-6, respectively. A summary of the results is presented in Table 1 and in Figures 11-16. The results show the RMS power consumption for 6 packs of compressors with both cases and cold rooms participating in the DSR event using the candidacy algorithm (with and without applying a pressure offset). It can be seen that the time required for the refrigeration system to return to normal power consumption after exiting a DSR event is not the same for all tests. This is due to the load characteristics and other operational procedures applied to the system prior to responding to the DSR event, and ultimately limits the availability of the system to respond to subsequent DSR commands.

To investigate the operational capacity of the refrigeration system in terms of demand on refrigerant in order to supply a minimum level of refrigerant to the fridges and freezers during a DSR event, one compressor per pack is forced to be kept operational during a DSR; limiting operation to 1 compressor per pack 'Load Shed Mode' for 30 minutes max, as shown in Figure 13. No pressure offset is applied under this scenario due to system controlling constraints. It can be seen that one LT pack leaves the Load Shed Mode as it exceeded the pressure limit. This scenario shows an improvement of $\sim 50 \%$ in the level of power shed capacity during the DSR, as can be seen by comparing the results of Figures 11-12 with Figure 13.

When a defrost (schedule 1) is applied, it is notable that the average power consumption is higher when the DSR event occurs within the second half of the hour compared to scenarios when a DSR occurs within the first half of the hour. This is due to the re-cooling process taking place during the last $15 \mathrm{~min}$ of the hour. Nevertheless, applying a pressure offset assists in lowering the power consumption by reducing the number of running compressors and shifting the re-cooling process out of the DSR event, as shown in Figures 11-16, respectively, and Appendix A, Table A.2, tests 1-6, respectively.

It is notable that the average power consumption during a DSR for tests associated with the re-cooling processes and a pressure offset is approximately equal to that for tests occurring outside re-cooling processes with no pressure offset. The worst-case scenario is when a DSR event is triggered during a re-cooling process and associated with no pressure offset. It can be seen from the tests that the system exhibits a power profile that is characteristic of normal steady operation for around 15 minutes post DSR, followed by a significant increase in power consumption between 15-20 minutes. This is due to a high proportion of HT cases exiting their defrost cycle using 'time termination' (40mins), hence leading to a synchronizing of power requirements. Energy consumption and energy saving benefits during 3 hours of operation (before, through out, and post secondary DSR) in response to a secondary FFR DSR for a retail refrigeration system are shown in Figure 17. The elevation of suction pressure for night operation (often referred as night set back) is a common practice to save energy in supermarkets where the load on the cabinets is relatively low. Elevating suction pressure during the DSR leads to a warmer evaporating temperature and a more efficient refrigeration cycle; since the coefficient of performance (COP) increases with the suction pressure. From the store trials, it is clear that even after recovery is complete, the DSR events themselves also achieve an overall energy saving in addition to the intended load shed. Since any reduction in heat load to the cabinets during the DSR event is expected to be small, it is most likely that the energy savings result from the elevated suction pressure during the DSR event. Furthermore, it is likely that a reduced load on the pack would reduce heat rejection from the condenser unit and hence reduce the power consumption, thereby 
providing further savings during the DSR event (although an elevated condensing temperature may offset this during recovery). Since the application of the DSR candidacy algorithm is not detrimental to food storage temperature, it is feasible to use the same network infrastructure and control system to facilitate more efficient pack operation during times of no DSR. Or, more sophisticated control of suction pressure for the pack can be investigated for dynamically optimizing the set point based on cabinet temperature models.

Table 1: Behaviour of the refrigeration systems of 6 packs of compressors with cases \& cold rooms in responding to secondary FFR DSR event, based on use of the candidacy algorithm, associated with two defrost schedules (with and without applying a pressure offset).

\begin{tabular}{|c|c|c|}
\hline Figure no & Behaviour of the system during DSR & $\begin{array}{c}\text { Behaviour of the system after exiting DSR, and the time of returning to } \\
\text { normal power consumption (RNO) after exiting DSR }\end{array}$ \\
\hline 11 & $\begin{array}{l}\text { Increase in power consumption due to } \\
\text { demand on refrigerant by the non- } \\
\text { candidate cases and the re-cooling } \\
\text { process. }\end{array}$ & $\begin{array}{l}\text { After } 15 \text { mins from exiting the DSR, an increase in power consumption } \\
\text { from } 50 \text { to } 110 \mathrm{~kW} \text { due to exiting defrost cycles for the majority of cases. } \\
\text { (RNO: } 61 \text { minutes). }\end{array}$ \\
\hline 12 & $\begin{array}{l}\text { Increase in power consumption due to } \\
\text { demand on refrigerant by the non- } \\
\text { candidate cases. }\end{array}$ & $\begin{array}{l}\text { After } 15 \text { mins from exiting the DSR, an increase in power consumption } \\
\text { from } 45 \text { to } 115 \mathrm{~kW} \text { due to exiting defrost cycles for the majority of cases. } \\
\text { (RNO: } 40 \text { minutes). }\end{array}$ \\
\hline 13 & $\begin{array}{l}\text { Around } 50 \% \text { reduction in power } \\
\text { consumption during the DSR event } \\
\text { due to the impact of Load Shed Mode } \\
\text { (i.e. limiting } 1 \text { comp per pack). }\end{array}$ & $\begin{array}{l}\text { Gradual increase in power from } 20 \text { to } 40 \mathrm{~kW} \text { during the first } 3 \text { mins, } \\
\text { followed by an increase in power from } 40 \text { to the peak of } 80 \mathrm{~kW} \text { for } \\
\text { around } 12 \text { mins due to the re-cooling process, is then followed by an } \\
\text { increase in power consumption from } 50 \text { to } 125 \mathrm{~kW} \text { due to exiting defrost } \\
\text { cycles for the majority of cases. (RNO: } 55 \text { minutes). }\end{array}$ \\
\hline 14 & $\begin{array}{l}\text { Increase in power consumption due to } \\
\text { demand on refrigerant by the non- } \\
\text { candidate cases }\end{array}$ & $\begin{array}{l}\text { Sudden increase in power due to returning to normal offset continued for } \\
\text { around } 3 \text { mins, then system remained in normal operation for around } 12 \\
\text { mins, followed by increase in power consumption from } 45 \text { to } 110 \mathrm{~kW} \\
\text { due to exiting defrost cycles for the majority of cases. } \\
\text { (RNO: } 34 \text { minutes). }\end{array}$ \\
\hline 15 & $\begin{array}{l}\text { Increase in power consumption due to } \\
\text { demand on refrigerant by the non- } \\
\text { candidate cases. }\end{array}$ & $\begin{array}{l}\text { Gradual increase in power and the system remained in normal operation } \\
\text { for around } 15 \text { mins, followed by increase in power consumption from } 45 \\
\text { to } 125 \mathrm{~kW} \text { due to exiting defrost cycles for the majority of cases. (RNO: } \\
52 \text { minutes). }\end{array}$ \\
\hline 16 & $\begin{array}{l}\text { Increase in power consumption due to } \\
\text { demand on refrigerant by the non- } \\
\text { candidate cases. }\end{array}$ & $\begin{array}{l}\text { Sudden increase in power due to returning to normal offset, continued for } \\
\text { around } 3 \text { mins, followed by another increase in power for around } 12 \\
\text { mins, followed by increase in power consumption from } 50 \text { to } 110 \mathrm{~kW} \\
\text { due to exiting defrost cycles for the majority of cases. (RNO: } 40 \\
\text { minutes). }\end{array}$ \\
\hline
\end{tabular}

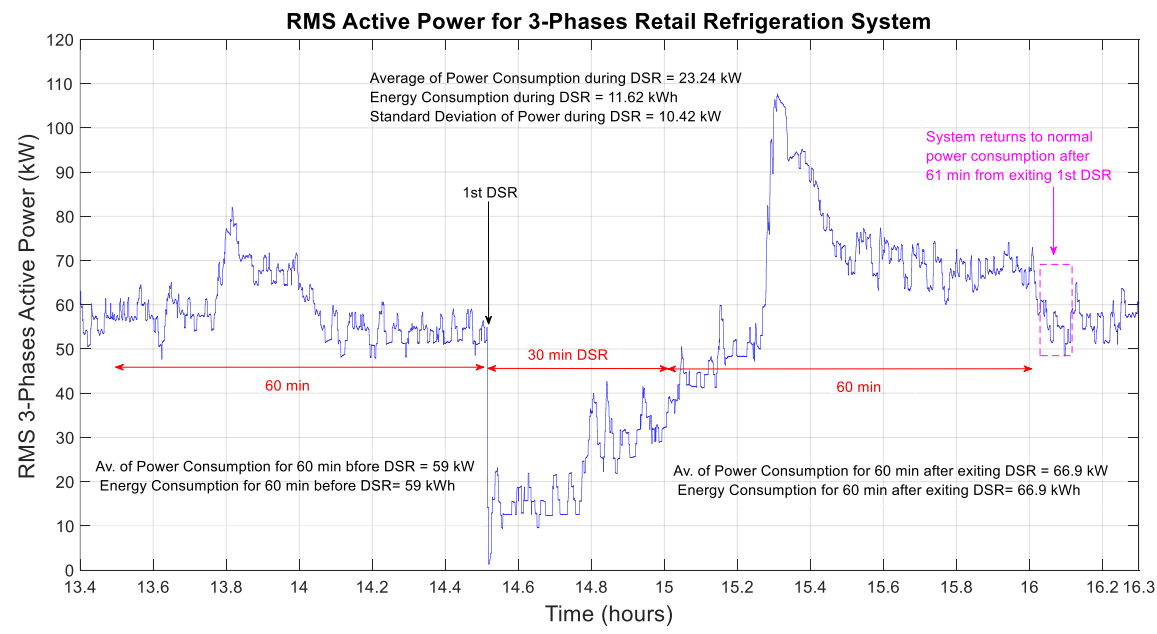

Figure 11: RMS power consumption for 6 packs of compressors, with cases \& cold rooms participating in the secondary FFR DSR event, based on the candidacy algorithm, without applying a pressure offset, under defrost schedule-1, DSR is triggered at 14:30 pm, (Test no 1, Table A.2). 


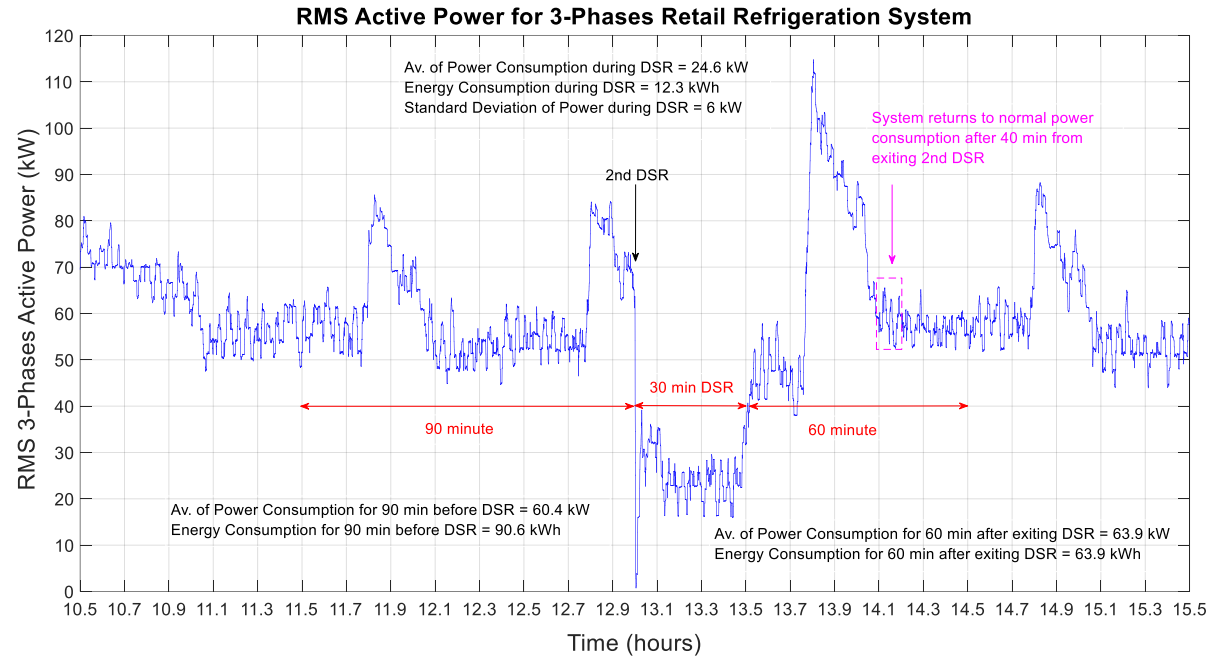

Figure 12: RMS power consumption for 6 packs of compressors, with cases \& cold rooms participating in the secondary FFR DSR event, based on the candidacy algorithm, without applying a pressure offset, under defrost schedule-1, DSR is triggered at 13:00 pm, (Test no 2, Table A.2).

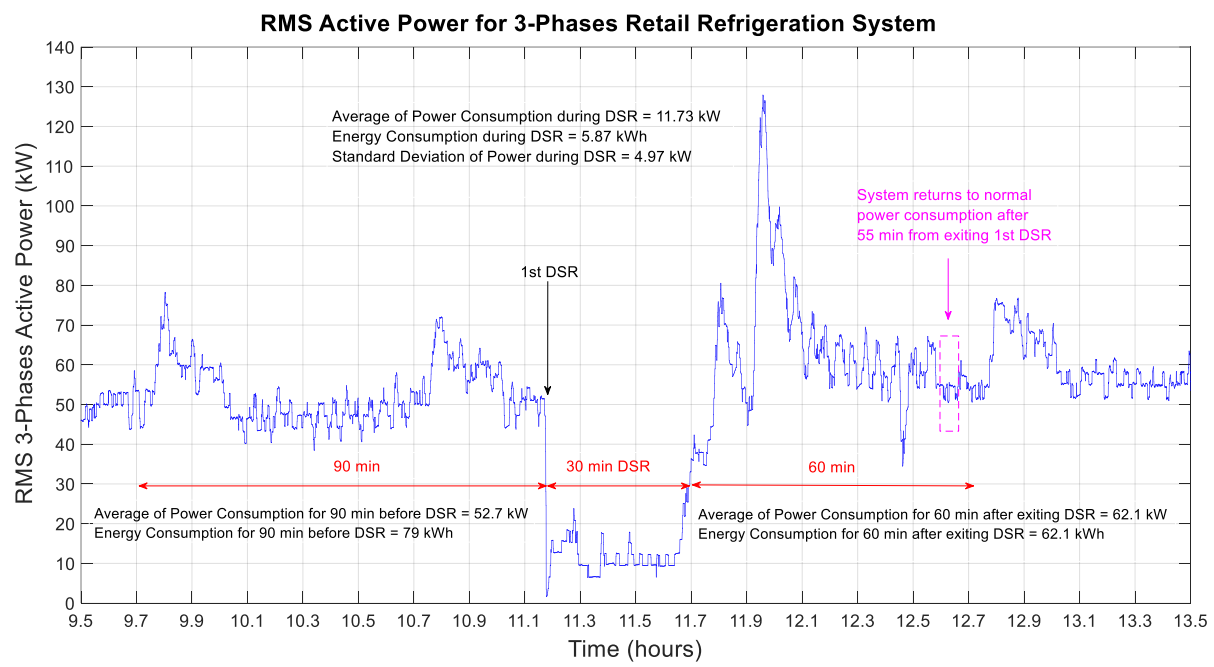

Figure 13: RMS power consumption for 6 packs of compressors, with cases \& cold rooms participating in the secondary FFR DSR event, based on the candidacy algorithm, without applying a pressure offset, under defrost schedule-1, associated with limiting 1 comp per pack "Load Shed Mode" 30 min max, DSR is triggered at 11:10 am, (Test no 3, Table A.2).

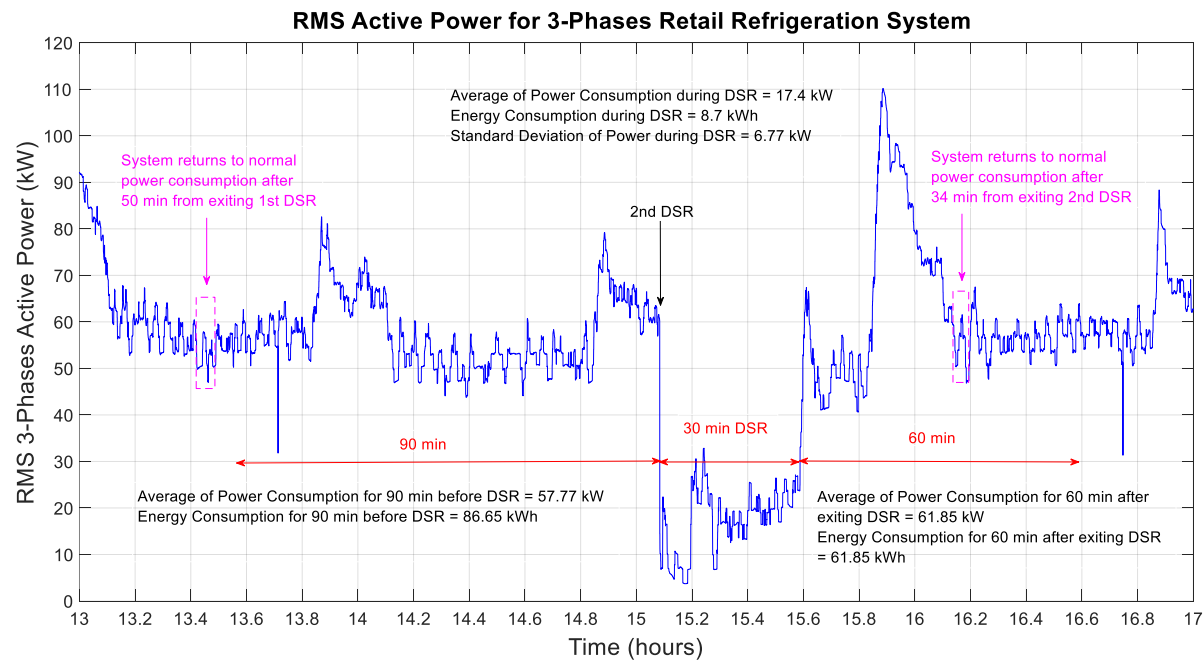

Figure 14: RMS power consumption for 6 packs of compressors, with cases \& cold rooms participating in the secondary FFR DSR event, based on the candidacy algorithm, with applying a pressure offset (LT=0.8, HT=1.1) for $30 \mathrm{~min}$, under defrost schedule-1, DSR is triggered at 15:04 pm (Test no 4, Table A.2). 


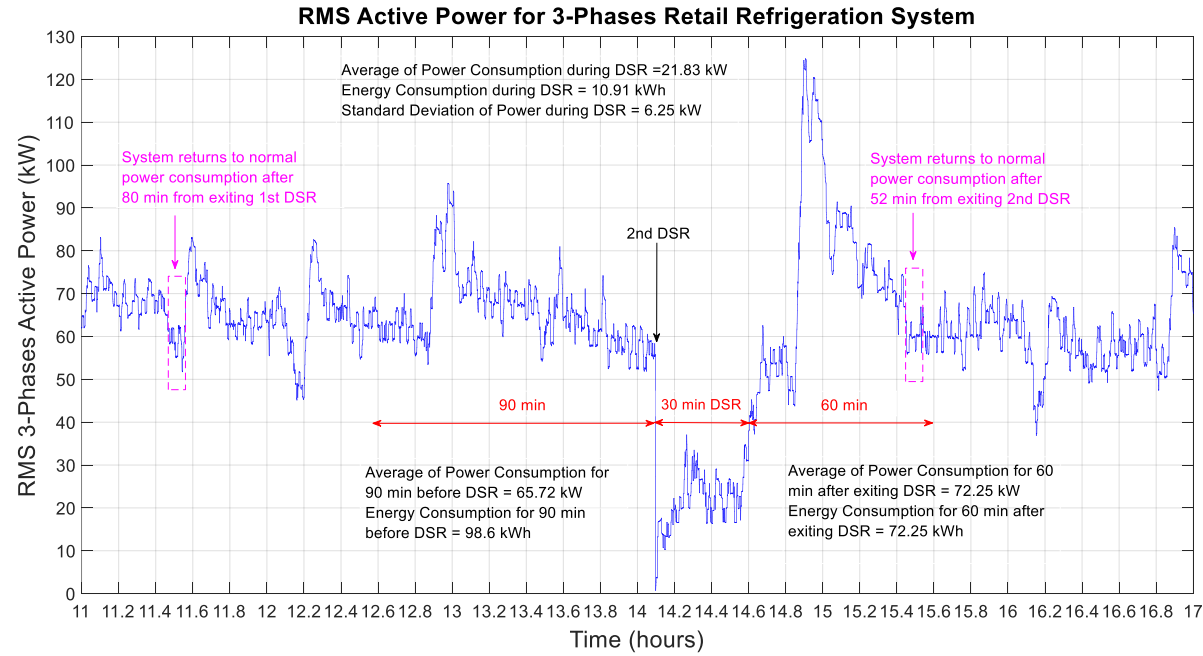

Figure 15: RMS power consumption for 6 packs of compressors, with cases \& cold rooms participating in the secondary FFR DSR event, based on the candidacy algorithm, without applying a pressure offset, under defrost schedule-2, DSR is triggered at 14:05 pm, (Test no 5, Table A.2).

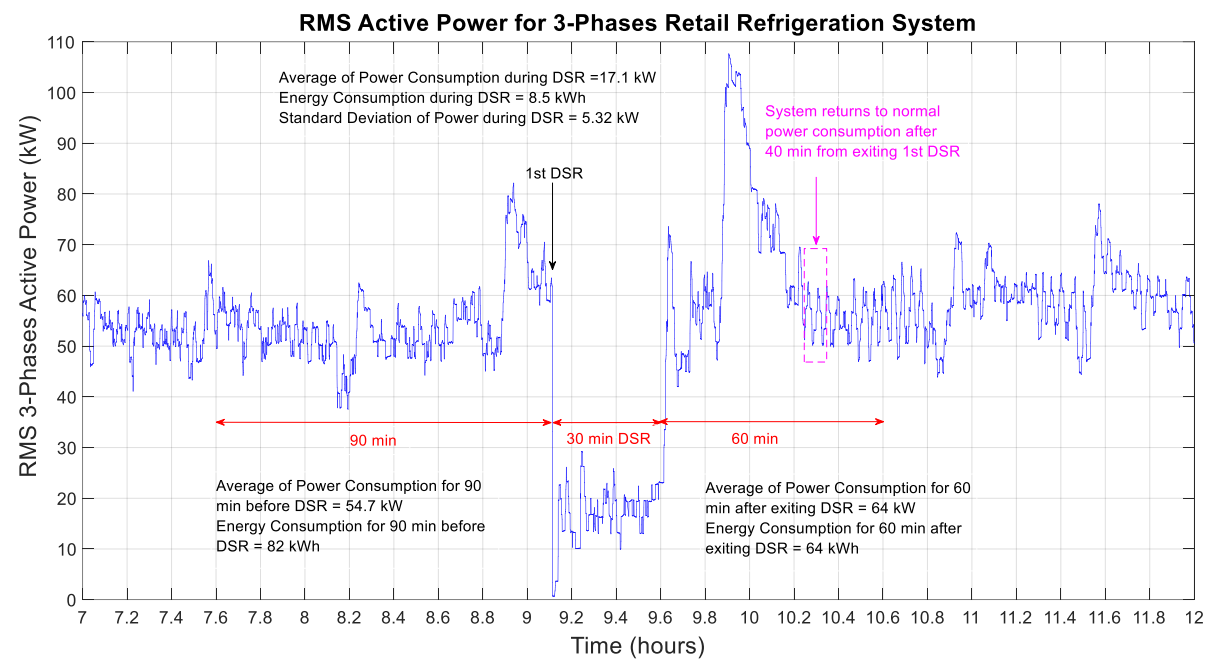

Figure 16: RMS power consumption for 6 packs of compressors, with cases \& cold rooms participating in the secondary FFR DSR event, based on the candidacy algorithm, with applying a pressure offset (LT=0.8, HT=1.1) for $30 \mathrm{~min}$, under defrost schedule-2, DSR is triggered at 09:05 am (Test no 6, Table A.2).

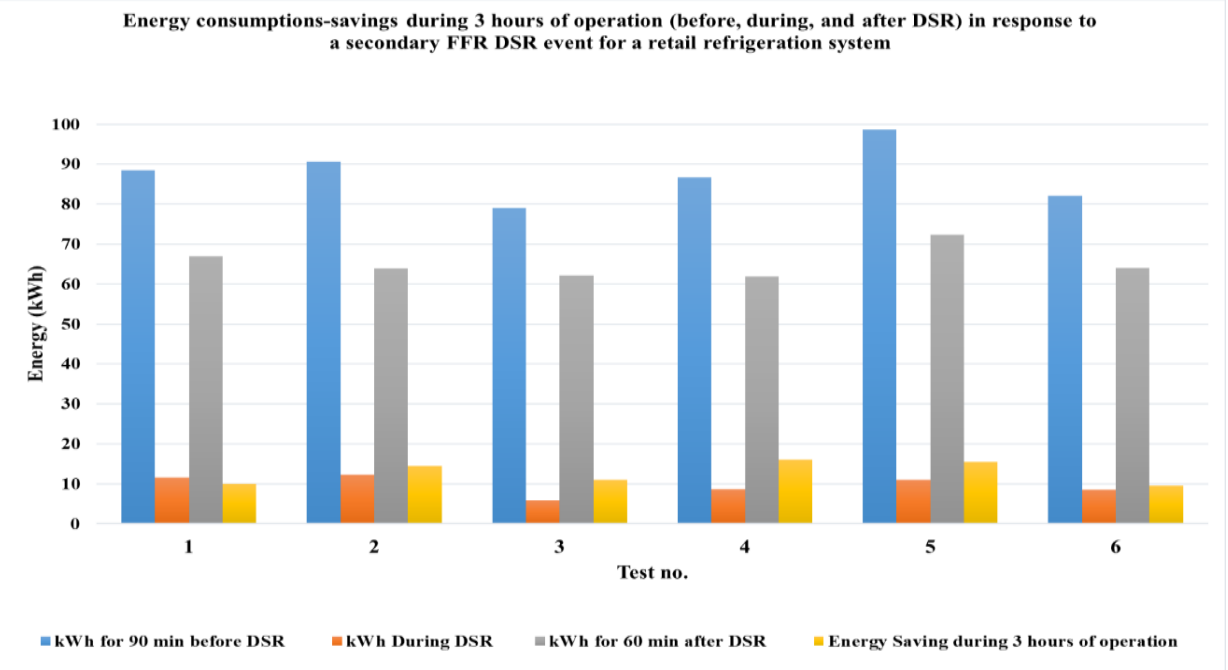

Figure 17: Energy consumptions-savings during 3 hours of operation (before, through out, and post secondary DSR) in response to a secondary FFR DSR event for a retails refrigeration system. 


\section{Simultaneous DSR for Multi-Store Refrigeration Systems}

A simultaneous secondary FFR DSR testing event was carried out on Nov. 2018 on three retail stores located in three different geographical regions of the UK as shown in Figure 2 above. The first store, located in Maidstone Grover Green south east of England, comprises of 6 packs of compressors (2 LTs and 4 HTs) and 110 cases and cold rooms. The second store, located in Holbeach, East of England, comprises of 3 packs of compressors (2 LTs and 1 HT) and 51 cases and cold rooms. The third store, located in Chesterfield, the East Midlands of England, comprises of 3 packs of compressors (2 LTs and 1 HT) and 66 cases and cold rooms. The test is implemented while the refrigeration systems were on a schedule-1 defrost (i.e. every hour defrost cycle), based on the candidacy algorithm associated with applying a pressure offset (LT=0.8, and HT=1.1). The DSR event is triggered by putting the cases and cold rooms into defrost by shutting down the valves of LT cases for 30 minutes and putting HT cases on defrost for 40 minutes, or until the HT system leaves defrost by reaching $8{ }^{\circ} \mathrm{C}$ temperature limit, then after 25 seconds, all the 12 packs are turned OFF (pulsing OFF-ON) (again allowing the remaining refrigerant in the system to flow back to the suction line of the compressors). The DSR is triggered at 14:41:36. The measured test results are given in Figure 18, which show the RMS power consumption for the 12 packs of compressors, with 227 cases \& cold rooms participating in DSR event, based on selection by the candidacy algorithm. Power consumption at the beginning of the DSR was $\sim 112 \mathrm{~kW}$ and after 25 seconds the power reduced to $3 \mathrm{~kW}$. The level of power shed is therefore $109 \mathrm{~kW}(\sim 0.11 \mathrm{MW})$ and the mean power consumption during the 30 mins of the DSR event is $30.2 \mathrm{~kW}$. Therefore, the rate of the power shed at the beginning of DSR is $(109 \mathrm{~kW} / 112 \mathrm{~kW}) * 100=97.3 \%$, and $27 \%$ during 30 mins DSR event. In summary, from the test results (i) the energy consumption for the preceding 90 minutes prior to the DSR is $179 \mathrm{kWh}$, and (ii) the energy consumption during the 30 minutes DSR event is $15.1 \mathrm{kWh}$, and (iii) the energy consumption for 60 minutes post DSR is $136.6 \mathrm{kWh}$. The energy saving (using Eq. 3 above) during the total 3 hours of operation is therefore $(179 \mathrm{kWh}-15.1 \mathrm{kWh}-136.6 \mathrm{kWh}=27.3 \mathrm{kWh})$. From the energy analysis of the store trials during 3 hours of operation (before, through out, and post secondary DSR), (refer to Tables A.1 \& A.2 in Appendix A), the DSR events facilitate an overall energy savings of between 3.8\% and 8.6\% at Riseholme and between 5.6\% and 9.3\% at Buckingham, and 9\% energy saving for the a simultaneous DSR event carried out on all three retail stores. This in addition to the benefits of the intended load shed.

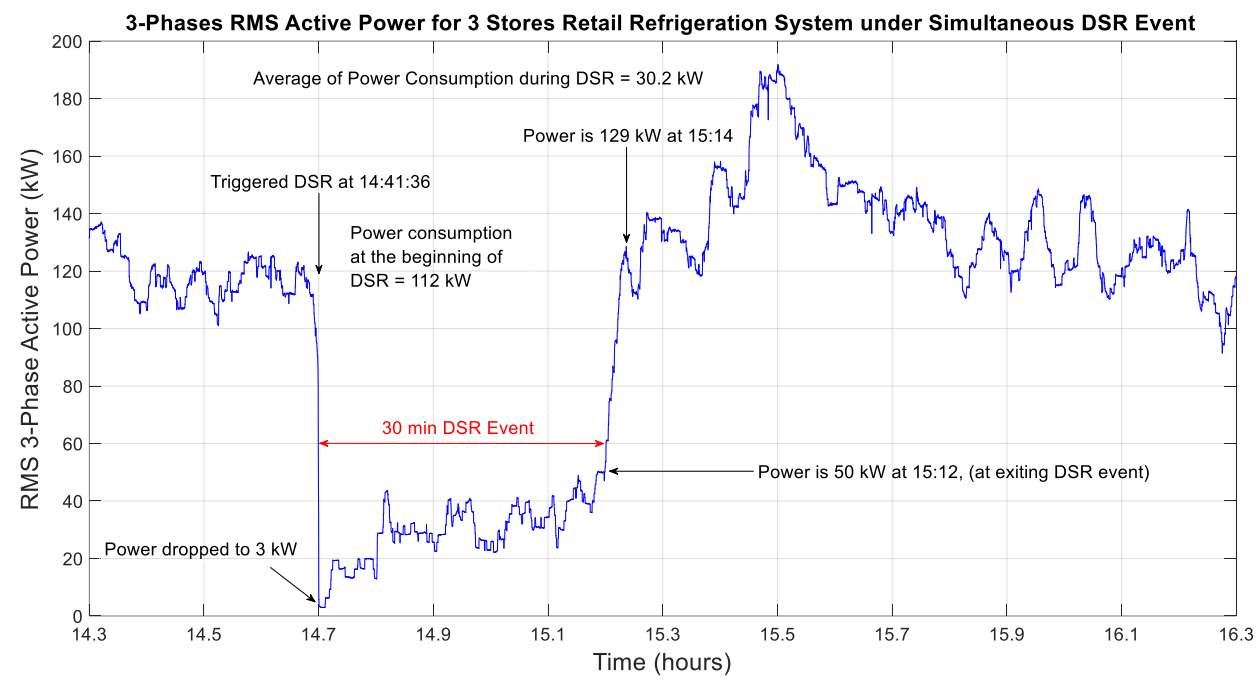

Figure 18: RMS power consumption for three retail stores comprises of 12 packs of compressors and 227 cases and cold rooms participating in the secondary FFR DSR event, based on the candidacy algorithm, associated with applying a pressure offset.

\section{Impact of DSR on the Performance of Local Power Supply System}

Following the method presented in [11,31], a $3 \Phi$ power system network simulation has been developed and validated with the real aggregated power data from trial stores. This is now will be used to investigate the impact of a synchronised turning-ON of the refrigeration systems post DSR on the local power supply system, and to simulate the impact of worst-case operational scenarios. The model uses the profile shown in Figure 18 as input to the $3 \Phi$ power network, Figure 19. For simplicity, a single line voltage is considered as being representative of the characteristics. To determine the impact of distance between the HV$11 \mathrm{kV}$ power source and the local stepdown transformer $11 \mathrm{kV} / 344 \mathrm{~V}$, various transmission line distances are selected, viz. 3, 6 , and $9 \mathrm{~km}$. The power network consists of the following primary components:

- High voltage $11 \mathrm{kV}, 50 \mathrm{~Hz}$ power source with resistive-inductive characteristics. The generator is set to always control the 
output active- and reactive- power.

- High voltage $11 \mathrm{kV}$ feeder cable, the distance from the HV-11kV power source to the local stepdown transformer $11 \mathrm{kV} / 344 \mathrm{~V}$ is selected to be 3,6 , and $9 \mathrm{~km}$.

- Step-down transformer (type Dyn11), where the secondary voltage leads the primary voltage by $30^{\circ}$.

- Low voltage $433 \mathrm{~V}$ feeder cable, the distance from the step-down transformer to the site main incomer is $30 \mathrm{~m}$.

- A $3 \Phi$ constant resistive-inductive floating Y connected load, with rated active power of $42.5 \mathrm{~kW}$ and $26.4 \mathrm{kVAR}$.

- A $3 \Phi$ dynamic load with the initial rated power of $42.5 \mathrm{~kW}$ and $26.4 \mathrm{kVAR}$.

Parameters, specifications and settings for the investigation are given in Appendix A, Table A.3. The results of the simulation after applying the power profile in Figure 18, are shown in Figure 20 (a) and (b), respectively. It can be seen that there is a $\sim 4 \mathrm{~V}$ (1\%) drop in line voltage due to the synchronised return to operation for refrigeration systems post DSR, corresponding to the operation of 12 packs of compressors. Such characteristics could degrade power system stability especially when many packs of compressors are rapidly synchronised post DSR, and will be particularly acute with long distribution distances between the HV$11 \mathrm{kV}$ power source and local stepdown transformer. Prior to the adoption of widespread distributed DSR, it is therefore necessary to carefully consider local network characteristics, particularly where systems based on renewable sources may reduce the supply stiffness.

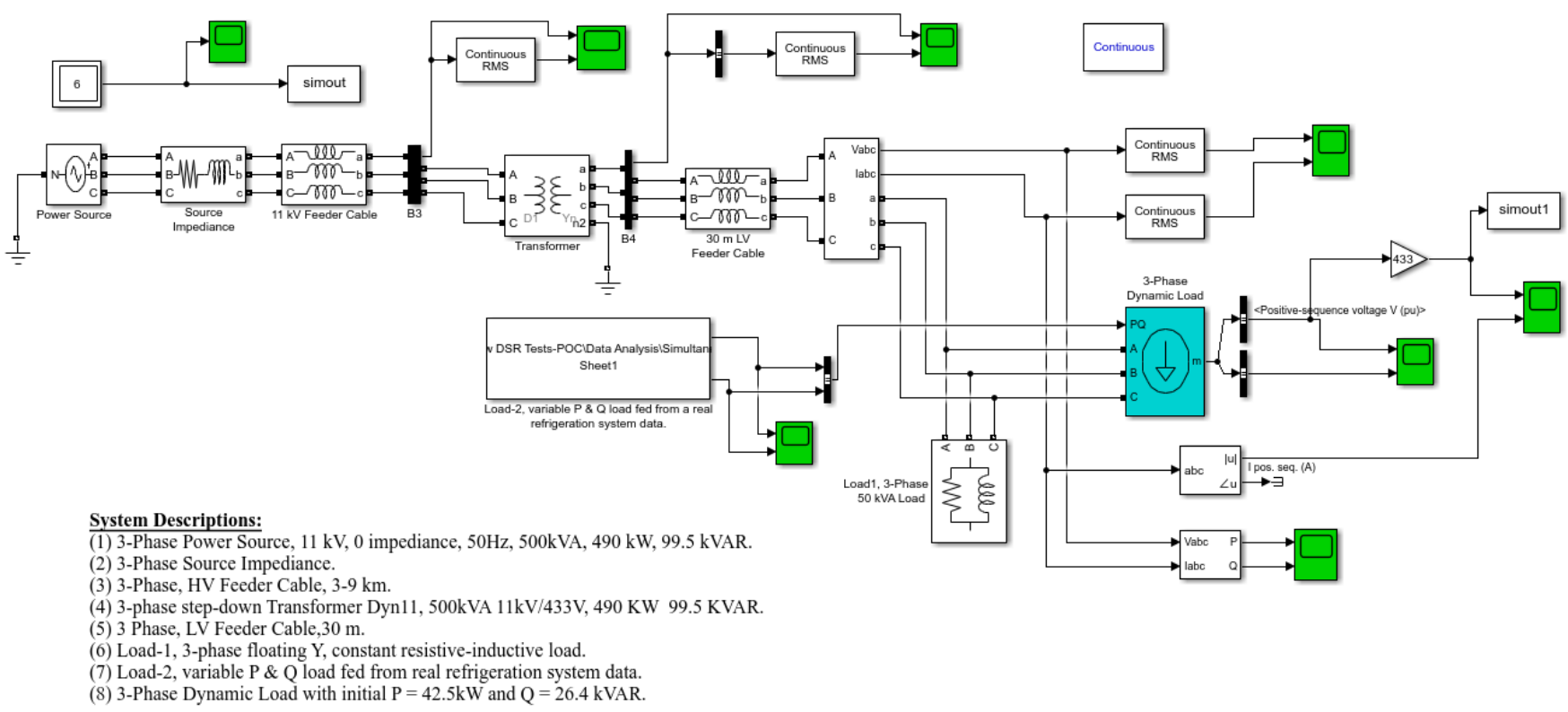

Figure 19: Simulink block diagram for a three phase power network.

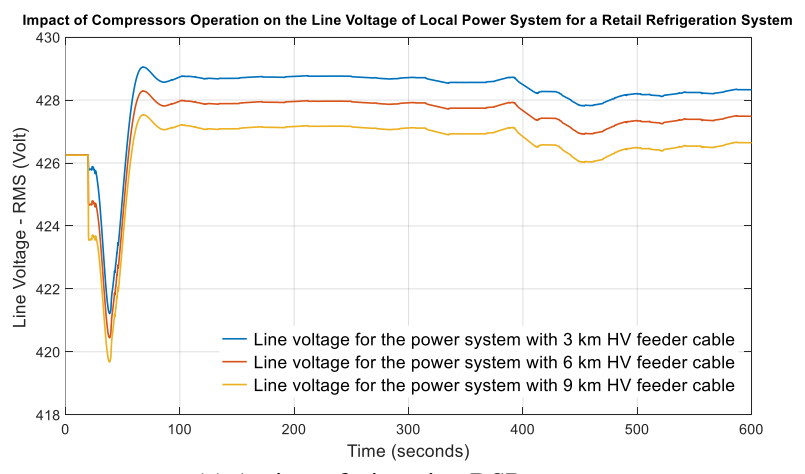

(a) At time of triggering DSR event

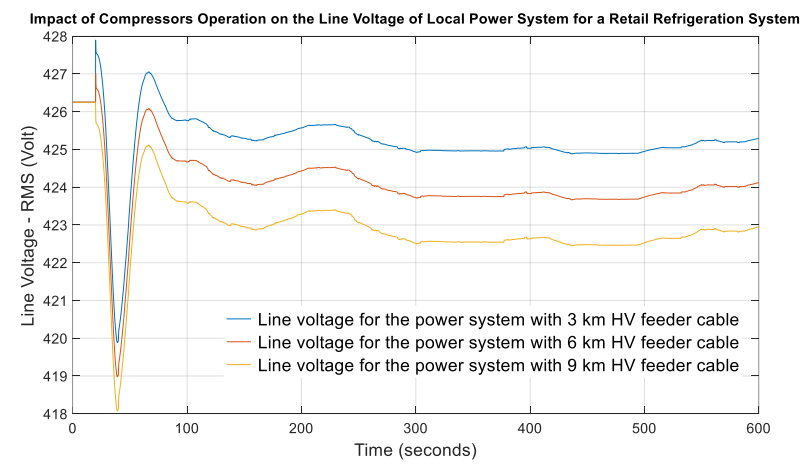

(b) After exiting DSR Event

Figure 20: Impact of the transient power consumption for refrigeration systems consisting of 12 packs of compressors in responding to DSR event on the line voltage of the local power system, for various power distribution distances. 


\section{Conclusion}

The active power profiles of distributed single and multi-pack refrigeration systems responding DSR events, and the impact of the subsequent re-synchronization of refrigeration loads at turn-ON post DSR, are experimentally investigated and analysed. Different operational scenarios of responding to a DSR are used. Specifically, experiments are conducted firstly on a refrigeration system representing a small retail store available at the Refrigeration Research Centre at The University of Lincoln, and also on a real superstore commercial retail refrigeration system in the UK. A candidacy algorithm to determine the rules for selecting appropriate stores for load shed prior to responding to a DSR is discussed. The algorithm is demonstrated to be nondetrimental to food storage temperature.

A Simulink model of a $3 \Phi$ power network is also developed to determine the impact of a synchronised turn-ON of a pack of compressors post DSR, and in particular on the line voltage of the local power supply system. Simulation studies are carried out using measured data as example candidate power profiles to investigate the impact of a post-DSR turn-ON synchronization of the selected loads. It is shown that $\sim 1 \%$ drop in line voltage can be expected in local networks with local loads consisting of 12 packs of compressors. Such characteristics can degrade power system stability, particularly when connected to non-stiff renewables sources over long transmission line distances. In summary, the use of aggregated refrigeration loads can contribute most effectively to the necessary load-shed by $97.3 \%$ at the beginning of DSR, and 27\% during 30 mins DSR, based on a simultaneous DSR event carried out on three retail stores.

It is shown that the best-case operational scenario for widely distributed commercial refrigerators to be used for DSR load shed, is when no re-cooling process initiated, and the worst-case scenario when a DSR is triggered during a re-cooling process when no pressure offset is applied. Importantly, it has been demonstrated that there is value in forcing the HT Cases to terminate their defrost by hitting the set point temp $8{ }^{\circ} \mathrm{C}$, since the termination time of the defrost cycle is then extended from 30 to 90 minutes. Under this condition the power consumption profile (post DSR) does not exhibit high peak power transients normally observed during the 15 mins post DSR. However, it should be noted that the temperature profile when defrosts are controlled based on temperature limits $\left(8{ }^{\circ} \mathrm{C}\right)$ is not yet known, and hence, the impact on food quality requires investigation prior to widespread adoption of this methodology. It is shown that elevated suction pressure during a DSR leads to a higher evaporating temperature and a more efficient refrigeration cycle i.e. the coefficient of performance (COP) increases with suction pressure. It is clear that a DSR event facilitate an overall energy up to $9 \%$ for a simultaneous DSR event carried out on all three retail stores. This is in addition to satisfying the intended load shed. The authors therefore stress the importance of a considerate choice of suction pressure offset values for packs of refrigeration cases that are expected to exit defrost during DSR, or cases that are not achieving target temperature. 
APPENDIX

Table A.1

Test of the refrigeration system at Riseholme Refrigeration Research Centre for the pack of 6 compressors on 18-07-2018

\begin{tabular}{|c|c|c|c|c|c|c|c|c|c|c|c|c|c|}
\hline \multirow[b]{2}{*}{$\begin{array}{l}\text { Test } \\
\text { No }\end{array}$} & \multirow{2}{*}{ 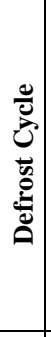 } & \multirow{2}{*}{$\begin{array}{l}\text { DSR } \\
\text { Event } \\
\text { Time }\end{array}$} & \multirow[b]{2}{*}{ DSR Procedure } & \multirow[b]{2}{*}{$\begin{array}{l}\text { System } \\
\text { affected }\end{array}$} & \multirow[b]{2}{*}{$\begin{array}{l}\text { Console } \\
\text { Used }\end{array}$} & \multicolumn{2}{|c|}{$\begin{array}{c}\text { Average of Power } \\
\text { Consumption and } k W h \\
\text { Before and During DSR }\end{array}$} & \multicolumn{2}{|c|}{$\begin{array}{c}\text { Average of Power } \\
\text { Consumption and } k \text { Wh after } \\
\text { exiting DSR }\end{array}$} & \multirow{2}{*}{$\begin{array}{c}\text { Energy } \\
\text { Saving }\left(E_{s}\right) \\
\text { during } 3 \\
\text { hours of } \\
\text { operation } \\
E_{s}=E_{1}- \\
\left(E_{2}+E_{3}+E_{4}\right)\end{array}$} & \multirow{2}{*}{$\begin{array}{c}\text { Approx. } \\
\text { time to } \\
\text { back to } \\
\text { Normal } \\
\text { Operation } \\
\text { after } \\
\text { exiting } \\
\text { DSR }\end{array}$} & \multirow{2}{*}{$\begin{array}{l}\text { Ratio of } \\
\text { Energy } \\
\text { Saving } \\
\frac{E_{S} / 2}{E_{1}}\end{array}$} & \multirow[b]{2}{*}{$\begin{array}{l}\text { Related } \\
\text { Figures }\end{array}$} \\
\hline & & & & & & $\begin{array}{c}90 \mathrm{~min} \\
\text { before DSR } \\
\quad(\text { E1 })\end{array}$ & $\begin{array}{c}\text { During } 30 \\
\text { min of DSR } \\
\quad\left(E_{2}\right)\end{array}$ & $\begin{array}{l}\text { First } 30 \\
\text { min after } \\
\text { DSR } \\
\quad\left(E_{3}\right)\end{array}$ & $\begin{array}{l}\text { Second } 30 \\
\text { min after } \\
\text { DSR } \\
\quad\left(E_{4}\right)\end{array}$ & & & & \\
\hline 1 & 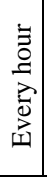 & 10:00 & $\begin{array}{l}\text { All cases/cold rooms in DSR, then after } 25 \mathrm{~s} \text {, all } 6 \\
\text { compressors turned OFF (pulsing OFF-ON), with an offset } \\
\text { (HT from } 3.4 \text { to } 4 \text { bar, and LT from } 0.7 \text { to } 1.3 \text { bar), for } 30 \\
\text { min. }\end{array}$ & $\begin{array}{c}\text { ALL } \\
\text { Systems } \\
\text { \& Packs }\end{array}$ & $\begin{array}{l}\text { Pack \& } \\
\text { Cases }\end{array}$ & $\begin{array}{c}12.5 \mathrm{~kW} \\
18.75 \mathrm{kWh}\end{array}$ & $\begin{array}{c}6.26 \mathrm{~kW} \\
3.13 \mathrm{kWh}\end{array}$ & $\begin{array}{r}14.75 \mathrm{~kW} \\
7.375 \mathrm{kWh}\end{array}$ & $\begin{array}{c}13 \mathrm{~kW} \\
6.5 \mathrm{kWh}\end{array}$ & $1.745 \mathrm{kWh}$ & $42 \min$ & $4.6 \%$ & Figure 5 \\
\hline 2 & 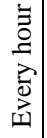 & $11: 30$ & $\begin{array}{l}\text { All cases/cold rooms in DSR, then after } 25 \mathrm{~s} \text {, all } 6 \\
\text { compressors turned OFF (pulsing OFF-ON), with no offset. }\end{array}$ & $\begin{array}{l}\text { ALL } \\
\text { Systems } \\
\text { \& Packs }\end{array}$ & $\begin{array}{l}\text { Pack \& } \\
\text { Cases }\end{array}$ & $\begin{array}{l}* * 13 \mathrm{~kW} \\
19.5 \mathrm{kWh}\end{array}$ & $\begin{array}{c}7.6 \mathrm{~kW} \\
3.8 \mathrm{kWh}\end{array}$ & $\begin{array}{l}14.4 \mathrm{~kW} \\
7.2 \mathrm{kWh}\end{array}$ & $\begin{array}{l}14 \mathrm{~kW} \\
7 \mathrm{kWh}\end{array}$ & $1.5 \mathrm{kWh}$ & $19 \mathrm{~min}$ & $3.8 \%$ & Figure 6 \\
\hline 3 & 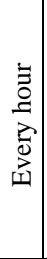 & $13: 30$ & $\begin{array}{l}\text { All cases/cold rooms in DSR, then after } 25 \mathrm{~s} \text {, all } 6 \\
\text { compressors turned OFF (pulsing OFF-ON), with an offset } \\
\text { (HT from } 3.4 \text { to } 4 \text { bar, and LT from } 0.7 \text { to } 1.3 \text { bar), for } 30 \\
\text { min. The termination time of defrost for the HT Cases (1-5) } \\
\text { has been extended from } 30 \text { to } 90 \text { min in order to force these } \\
\text { cases to terminate defrost by hitting the set point temp } 8^{\circ} \mathrm{C} \text {. }\end{array}$ & $\begin{array}{c}\text { ALL } \\
\text { Systems } \\
\text { \& Packs }\end{array}$ & $\begin{array}{l}\text { Pack \& } \\
\text { Cases }\end{array}$ & $\begin{array}{c}* 13 \mathrm{~kW} \\
19.5 \mathrm{kWh}\end{array}$ & $\begin{array}{c}7.1 \mathrm{~kW} \\
3.55 \mathrm{kWh}\end{array}$ & $\begin{array}{c}14.1 \mathrm{~kW} \\
7.05 \mathrm{kWh}\end{array}$ & $\begin{array}{l}13.8 \mathrm{~kW} \\
6.9 \mathrm{kWh}\end{array}$ & $2 \mathrm{kWh}$ & $2 \min$ & $5 \%$ & Figure 7 \\
\hline 4 & 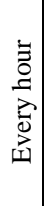 & $16: 00$ & $\begin{array}{l}\text { All cases/cold rooms in DSR, then after } 25 \mathrm{~s} \text {, all } 6 \\
\text { compressors turned OFF (pulsing OFF-ON), with no offset. } \\
\text { The termination time of defrost for the HT Cases }(1-5) \text { has } \\
\text { been extended from } 30 \text { to } 90 \mathrm{~min} \text { in order to force these } \\
\text { cases to terminate defrost by hitting the set point temp } 8^{\circ} \mathrm{C} \text {. }\end{array}$ & $\begin{array}{c}\text { ALL } \\
\text { Systems } \\
\text { \& Packs }\end{array}$ & $\begin{array}{c}\text { Pack \& } \\
\text { Cases }\end{array}$ & $\begin{array}{c}13.6 \mathrm{~kW} \\
20.4 \mathrm{kWh}\end{array}$ & $\begin{array}{c}6.5 \mathrm{~kW} \\
3.25 \mathrm{kWh}\end{array}$ & $\begin{array}{c}14.3 \mathrm{~kW} \\
7.15 \mathrm{kWh}\end{array}$ & $\begin{array}{c}13 \mathrm{~kW} \\
6.5 \mathrm{kWh}\end{array}$ & $3.5 \mathrm{kWh}$ & $32 \mathrm{~min}$ & $8.6 \%$ & Figure 8 \\
\hline
\end{tabular}

*** (based on the average of $30 \mathrm{~min}$ power data prorated to $90 \mathrm{~min}$ ).

* (based on the average of $60 \mathrm{~min}$ power data prorated to $90 \mathrm{~min}$ ). 
Table A.2

Tests of the refrigeration system at Buckingham Store for the system of 6 packs of compressors

\begin{tabular}{|c|c|c|c|c|c|c|c|c|c|c|c|c|c|}
\hline \multirow[b]{2}{*}{$\begin{array}{l}\text { Test } \\
\text { No }\end{array}$} & \multirow{2}{*}{ 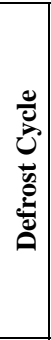 } & \multirow{2}{*}{$\begin{array}{c}\text { DSR } \\
\text { Event } \\
\text { Date \& } \\
\text { Time }\end{array}$} & \multirow[b]{2}{*}{ DSR Procedure } & \multirow[b]{2}{*}{$\begin{array}{l}\text { System } \\
\text { affected }\end{array}$} & \multirow[b]{2}{*}{$\begin{array}{c}\text { Console } \\
\text { Used }\end{array}$} & \multicolumn{2}{|c|}{$\begin{array}{c}\text { Average of Power } \\
\text { Consumption and } k W h \\
\text { Before and During DSR }\end{array}$} & \multicolumn{2}{|c|}{$\begin{array}{c}\text { Average of Power } \\
\text { Consumption and } k W h \text { after } \\
\text { exiting DSR }\end{array}$} & \multirow{2}{*}{$\begin{array}{c}\text { Energy } \\
\text { Saving }\left(E_{s}\right) \\
\text { during } 3 \\
\text { hours of } \\
\text { operation } \\
E_{s}=E_{1}- \\
\left(E_{2}+E_{3}+E_{4}\right)\end{array}$} & \multirow{2}{*}{$\begin{array}{l}\text { Approx. } \\
\text { time to } \\
\text { back to } \\
\text { Normal } \\
\text { Operation } \\
\text { after } \\
\text { exiting } \\
\text { DSR }\end{array}$} & \multirow{2}{*}{$\begin{array}{l}\text { Ratio of } \\
\text { Energy } \\
\text { Saving } \\
\frac{E_{S} / 2}{E_{1}}\end{array}$} & \multirow[b]{2}{*}{$\begin{array}{l}\text { Related } \\
\text { Figures }\end{array}$} \\
\hline & & & & & & $\begin{array}{c}90 \text { min } \\
\text { before DSR } \\
\quad\left(E_{1}\right)\end{array}$ & $\begin{array}{c}\text { During } 30 \\
\text { min of DSR } \\
\quad\left(E_{2}\right)\end{array}$ & $\begin{array}{c}\text { First } 30 \\
\text { min after } \\
\text { DSR } \\
\left(E_{3}\right)\end{array}$ & $\begin{array}{l}\text { Second } 30 \\
\text { min after } \\
\text { DSR } \\
\left(E_{4}\right)\end{array}$ & & & & \\
\hline 1 & 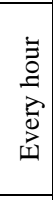 & $\begin{array}{c}16 / 2 / 18 \\
14: 30\end{array}$ & $\begin{array}{l}\text { Only Candidates of (cases \& cold rooms) in DSR } \\
\text { event, based on the candidacy algorithm and the } \\
\text { availability of these cases and cold rooms as } \\
\text { candidates, then after } 25 \mathrm{~s} \text { (pulsing OFF-ON) all the } \\
\text { packs, with no offset. }\end{array}$ & $\begin{array}{c}\text { ALL } \\
\text { Candidates }\end{array}$ & Candidacy & $\begin{array}{c}* 59 \mathrm{~kW} \\
88.5 \mathrm{kWh}\end{array}$ & $\begin{array}{c}23.24 \mathrm{~kW} \\
11.62 \mathrm{kWh}\end{array}$ & $\begin{array}{c}64.8 \mathrm{~kW} \\
32.4 \mathrm{kWh}\end{array}$ & $\begin{array}{c}69 \mathrm{~kW} \\
34.5 \mathrm{kWh}\end{array}$ & $10 \mathrm{kWh}$ & $61 \mathrm{~min}$. & $5.6 \%$ & $\begin{array}{c}\text { Figure } \\
11\end{array}$ \\
\hline 2 & 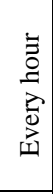 & $\begin{array}{c}19 / 2 / 18 \\
13: 00\end{array}$ & $\begin{array}{l}\text { Only candidates of (cases \& cold rooms) in DSR, } \\
\text { based on the candidacy algorithm and the } \\
\text { availability of these cases and cold rooms as } \\
\text { candidates, then after } 25 \mathrm{~s} \text { (pulsing OFF-ON) (all } \\
\text { the packs), with no offset. }\end{array}$ & $\begin{array}{c}\text { ALL } \\
\text { Candidates }\end{array}$ & Candidacy & $\begin{array}{c}60.4 \mathrm{~kW} \\
90.6 \mathrm{kWh}\end{array}$ & $\begin{array}{c}24.6 \mathrm{~kW} \\
12.3 \mathrm{kWh}\end{array}$ & $\begin{array}{c}67.4 \mathrm{~kW} \\
33.7 \mathrm{kWh}\end{array}$ & $\begin{array}{c}60.4 \mathrm{~kW} \\
30.2 \mathrm{kWh}\end{array}$ & $14.4 \mathrm{kWh}$ & $40 \mathrm{~min}$. & $8 \%$ & $\begin{array}{c}\text { Figure } \\
12\end{array}$ \\
\hline 3 & 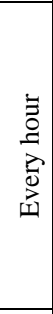 & $\begin{array}{c}07 / 3 / 18 \\
11: 10\end{array}$ & $\begin{array}{l}\text { Only candidates of (cases \& cold rooms) in DSR, } \\
\text { based on the candidacy algorithm and the } \\
\text { availability of these cases and cold rooms as } \\
\text { candidates, then after } 25 \mathrm{~s} \text { (pulsing OFF-ON) (all } \\
\text { the packs). Limiting to } 1 \text { comp per pack "Load } \\
\text { Shed Mode"- } 30 \text { min max - No offset can be } \\
\text { applied. (LT1 pack reset from Load shed due to } \\
\text { exceeding max pressure limit). }\end{array}$ & $\begin{array}{c}\text { ALL } \\
\text { Candidates }\end{array}$ & $\begin{array}{c}\text { Pack \& } \\
\text { Case }\end{array}$ & $\begin{array}{l}52.7 \mathrm{~kW} \\
79 \mathrm{kWh}\end{array}$ & $\begin{array}{l}11.73 \mathrm{~kW} \\
5.87 \mathrm{kWh}\end{array}$ & $\begin{array}{c}66 \mathrm{~kW} \\
33 \mathrm{kWh}\end{array}$ & $\begin{array}{c}58.2 \mathrm{~kW} \\
29.1 \mathrm{kWh}\end{array}$ & $11 \mathrm{kWh}$ & $55 \mathrm{~min}$ & $7 \%$ & $\begin{array}{c}\text { Figure } \\
13\end{array}$ \\
\hline 4 & 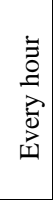 & $\begin{array}{c}09 / 3 / 18 \\
15: 04\end{array}$ & $\begin{array}{l}\text { Only Candidates of (cases \& cold rooms) in DSR } \\
\text { event, based on the candidacy algorithm and the } \\
\text { availability of these cases and cold rooms as } \\
\text { candidates, then after } 25 \mathrm{~s} \text { (pulsing OFF-ON) all the } \\
\text { packs, with offset (LT=0.8, HT=1.1) for } 30 \mathrm{~min} \text {. }\end{array}$ & $\begin{array}{c}\text { ALL } \\
\text { Candidates }\end{array}$ & Candidacy & $\begin{array}{c}57.77 \mathrm{~kW} \\
86.65 \mathrm{kWh}\end{array}$ & $\begin{array}{l}17.4 \mathrm{~kW} \\
8.7 \mathrm{kWh}\end{array}$ & $\begin{array}{c}66.5 \mathrm{~kW} \\
33.25 \mathrm{kWh}\end{array}$ & $\begin{array}{c}57.2 \mathrm{~kW} \\
28.6 \mathrm{kWh}\end{array}$ & $16.1 \mathrm{kWh}$ & $34 \mathrm{~min}$ & $9.3 \%$ & $\begin{array}{c}\text { Figure } \\
14\end{array}$ \\
\hline 5 & 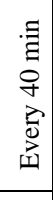 & $\begin{array}{c}03 / 4 / 18 \\
14: 05\end{array}$ & $\begin{array}{l}\text { Only Candidates of (cases/cold rooms) in DSR } \\
\text { event, based on the candidacy algorithm and the } \\
\text { availability of these cases and cold rooms as } \\
\text { candidates, then after } 25 \mathrm{~s} \text { (pulsing OFF-ON) all the } \\
\text { packs, with no offset. }\end{array}$ & $\begin{array}{c}\text { ALL } \\
\text { Candidates }\end{array}$ & Candidacy & $\begin{array}{l}65.72 \mathrm{~kW} \\
98.6 \mathrm{kWh}\end{array}$ & $\begin{array}{c}21.83 \mathrm{~kW} \\
10.91 \mathrm{kWh}\end{array}$ & $\begin{array}{c}73.4 \mathrm{~kW} \\
36.7 \mathrm{kWh}\end{array}$ & $\begin{array}{c}71.1 \mathrm{~kW} \\
35.55 \mathrm{kWh}\end{array}$ & $15.44 \mathrm{kWh}$ & $52 \mathrm{~min}$ & $7.8 \%$ & $\begin{array}{c}\text { Figure } \\
15\end{array}$ \\
\hline 6 & 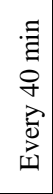 & $\begin{array}{c}04 / 4 / 18 \\
09.05\end{array}$ & $\begin{array}{l}\text { Only Candidates of (cases \& cold rooms) in DSR } \\
\text { event, based on the candidacy algorithm and the } \\
\text { availability of these cases and cold rooms as } \\
\text { candidates, then after } 25 \mathrm{~s} \text { (pulsing OFF-ON) all the } \\
\text { packs, with offset (LT=0.8, HT=1.1) for } 30 \text { min. }\end{array}$ & $\begin{array}{c}\text { ALL } \\
\text { Candidates }\end{array}$ & Candidacy & $\begin{array}{l}54.7 \mathrm{~kW} \\
82 \mathrm{kWh}\end{array}$ & $\begin{array}{l}17.1 \mathrm{~kW} \\
8.5 \mathrm{kWh}\end{array}$ & $\begin{array}{c}70 \mathrm{~kW} \\
35 \mathrm{kWh}\end{array}$ & $\begin{array}{c}58 \mathrm{kw} \\
29 \mathrm{kWh}\end{array}$ & $9.5 \mathrm{kWh}$ & $40 \mathrm{~min}$ & $5.8 \%$ & $\begin{array}{c}\text { Figure } \\
16\end{array}$ \\
\hline
\end{tabular}

* (based on the average of $60 \mathrm{~min}$ power data prorated to $90 \mathrm{~min}$ ). 
Table A.3

Values of the parameters, specifications and settings for the components of the Simulink model of power system

\begin{tabular}{|c|c|c|c|c|}
\hline Rating & Power Source & $\begin{array}{c}\text { High Voltage } \\
\text { Feeder } \\
\end{array}$ & Step Down Transformer & Low Voltage Feeder \\
\hline Voltage & $11 \mathrm{kV}$ & - & $11 \mathrm{kV} / 433 \mathrm{~V}$ & $433 \mathrm{~V}$ \\
\hline Current & $39.4 \mathrm{~A}$ & - & $26.24 \mathrm{~A} / 666.7 \mathrm{~A}$ & - \\
\hline Power Factor & $0.98 *$ & - & $0.98 *$ & - \\
\hline Apparent Power & $750 \mathrm{kVA} *$ & - & $500 \mathrm{kVA}$ & - \\
\hline Active Power & $736 \mathrm{~kW}$ & - & $490 \mathrm{~kW}$ & - \\
\hline Reactive Power & 149.3 kVAR & - & $99.5 \mathrm{kVAR}$ & - \\
\hline 3-phase Self-Impedance & 1 ohm, 1 mH & $\begin{array}{c}0.1153 \mathrm{Ohm} / \mathrm{km}, \\
1.048 \mathrm{mH} / \mathrm{km}\end{array}$ & - & $\begin{array}{c}0.1153 \mathrm{Ohm} / \mathrm{km}, 1.048 \\
\mathrm{mH} / \mathrm{km}\end{array}$ \\
\hline 3-phase Mutual-Impedance & - & $\begin{array}{c}0.4130 \mathrm{Ohm} / \mathrm{km}, \\
3.321 \mathrm{mH} / \mathrm{km} \\
\end{array}$ & - & $\begin{array}{c}0.4130 \mathrm{Ohm} / \mathrm{km}, 3.321 \\
\mathrm{mH} / \mathrm{km}\end{array}$ \\
\hline 3-phase Primary Winding Impedance & - & - & $\begin{array}{c}0.024485 \text { Ohm, } 1.9244 \\
\mathrm{mH} \\
\end{array}$ & - \\
\hline 3-phase Secondary Winding Impedance & - & - & $\begin{array}{c}6.1714 \times 10^{-5} \mathrm{Ohm}, \\
4.8504 \times 10^{-6} \mathrm{H} \\
\end{array}$ & - \\
\hline 3-Phase Magnetization Impedance & - & - & 4534.3 Ohm, 12.028 H & - \\
\hline
\end{tabular}

* Assumed values 


\section{Acknowledgment}

This project of research is supported by Innovate UK (grant number 54043-400273). The authors would like to thank project partners: Tesco PLC, IMS Evolve Ltd, Global Smart Transformations Ltd, Grimsby Institute's Food Refrigeration and Process Engineering Research Centre (FRPERC), and ECH Engineering. Special gratitude must go to Mr Lee Harpham from IMS Evolve and Dr Edward Hammond from ECH Engineering for their assistance and guidance and advice during field experiments at Riseholme Refrigeration Research Centre.

\section{References}

1. Shafiei, S.E., H. Rasmussen, and J. Stoustrup, Modeling supermarket refrigeration systems for demand-side management. Energies, 2013. 6(2): p. 900-920.

2. Kies, A., B.U. Schyska, and L. von Bremen, The demand side management potential to balance a highly renewable European power system. Energies, 2016. 9(11): p. 955.

3. Angeli, D. and P.-A. Kountouriotis, A stochastic approach to "dynamic-demand" refrigerator control. IEEE Transactions on control systems technology, 2012. 20(3): p. 581-592.

4. $\quad$ NationalGrid, Firm Frequency Response (FFR). 2018, National Grid: UK.

5. Cheng, M., J. Wu, S.J. Galsworthy, et al., Performance of industrial melting pots in the provision of dynamic frequency response in the Great Britain power system. Applied Energy, 2017. 201: p. 245-256.

6. Teng, F., M. Aunedi, D. Pudjianto, et al., Benefits of demand-side response in providing frequency response service in the future GB power system. Frontiers in Energy Research, 2015. 3: p. 36.

7. Granell, R., C.J. Axon, D.C. Wallom, et al., Power-use profile analysis of non-domestic consumers for electricity tariff switching. Energy Efficiency, 2016. 9(3): p. 825-841.

8. Grünewald, P. and J. Torriti, Demand response from the non-domestic sector: Early UK experiences and future opportunities. Energy Policy, 2013. 61: p. 423-429.

9. Kamel, F. and M. Marwan, Demand-side response smart grid technique for optimized energy use, in Innovation in Power, Control, and Optimization: Emerging Energy Technologies. 2012, IGI Global. p. 137-163.

10. Tassou, S.A., M. Kolokotroni, B. Gowreesunker, et al., Energy demand and reduction opportunities in the UK food chain, in Proceedings of the Institution of Civil Engineers-Energy. 2014, ICE Publishing. p. 162-170.

11. Saleh, I.M., A. Postnikov, C. Arsene, et al., Impact of Demand Side Response on a Commercial Retail Refrigeration System. Energies, 2018. 11(2): p. 371.

12. Stadler, I., Power grid balancing of energy systems with high renewable energy penetration by demand response. Utilities Policy, 2008. 16(2): p. 90-98.

13. Postnikov, A., I. Albayati, S. Pearson, et al., Facilitating static firm frequency response with aggregated networks of commercial food refrigeration systems. Applied Energy, 2019. 251: p. 113357.

14. Atzeni, I., L.G. Ordóñez, G. Scutari, et al., Demand-side management via distributed energy generation and storage optimization. IEEE Transactions on Smart Grid, 2013. 4(2): p. 866-876.

15. Hviid, J. and M.B. Kjœrgaard. The retail store as a smart grid ready building: Current practice and future potentials. in 2018 IEEE Power \& Energy Society Innovative Smart Grid Technologies Conference (ISGT). 2018. IEEE.

16. Muhssin, M.T., L.M. Cipcigan, S.S. Sami, et al., Potential of demand side response aggregation for the stabilization of the grids frequency. Applied Energy, 2018. 220: p. 643-656.

17. Conte, F., S. Massucco, F. Silvestro, et al., Stochastic modelling of aggregated thermal loads for impact analysis of demand side frequency regulation in the case of Sardinia in 2020. International Journal of Electrical Power \& Energy Systems, 2017. 93: p. 291-307.

18. Buzelin, L., S. Amico, J. Vargas, et al., Experimental development of an intelligent refrigeration system. International Journal of Refrigeration, 2005. 28(2): p. 165-175.

19. Snijders, C., U. Matzat, and U.-D. Reips, "Big Data": big gaps of knowledge in the field of internet science. International Journal of Internet Science, 2012. 7(1): p. 1-5. 
20. Brady, N. and J. Walsh, Using a Big Data Analytics Approach to Unlock the Value of Refrigeration Case Parametric Data. ASHRAE Transactions, 2015. 121: p. 1AAA.

21. Tang, X. and J.V. Milanović. Assessment of the impact of demand-side management on distribution network voltage stability. in CIRED. 2017. Glasgow, UK: IET.

22. Larsen, L.F., C. Thybo, R. Wisniewski, et al. Synchronization and desynchronizing control schemes for supermarket refrigeration systems. in 16th IEEE International Conference on Control Applications. 2007. Singapore: IEEE.

23. Kremers, E., J.M.G. de Durana, O. Barambones, et al., Synchronisation phenomena in electrical systems: emergent oscillation in a refrigerator population, in Complex Systems Design \& Management. 2013, Springer. p. 273-284.

24. Short, J.A., D.G. Infield, and L.L. Freris, Stabilization of grid frequency through dynamic demand control. IEEE Transactions on power systems, 2007. 22(3): p. 1284-1293.

25. Stadler, M., W. Krause, M. Sonnenschein, et al., Modelling and evaluation of control schemes for enhancing load shift of electricity demand for cooling devices. Environmental Modelling \& Software, 2009. 24(2): p. 285-295.

26. Anderson, P.M. and M. Mirheydar, A low-order system frequency response model. IEEE Transactions on Power Systems, 1990. 5(3): p. 720-729.

27. Borsche, T., U. Markovic, and G. Andersson, A new algorithm for primary frequency control with cooling appliances. Computer Science-Research and Development, 2016. 31(1-2): p. 89-95.

28. Kremers, E., J. Marı, and O. Barambones, Emergent synchronisation properties of a refrigerator demand side management system. Applied energy, 2013. 101: p. 709-717.

29. A. Postnikov, A. Zolotas, C. Bingham, et al. Modelling of Thermostatically Controlled Loads to Analyse the Potential of Delivering FFR DSR with a Large Network of Compressor Packs. in EMS on Mathematical Modelling and Computer Simulation. 2017. Manchester, UK: IEEE.

30. Lawrence, J.M.W., Monitoring Refrigerated Units, in U.S. Patent 1992: U.S.

31. Saleh, I., A. Postnikov, C. Bingham, et al., Aggregated power profile of a large network of refrigeration compressors following FFR DSR events, in International Conference on Energy Engineering and Smart Grids, (ESG 2018). 2018: Cambridge, UK. 